\title{
EXPERIMENTAL TESTS OF STEEL UNSTIFFENED DOUBLE SIDE JOINTS WITH FLUSH AND EXTENDED END PLATE
}

\begin{abstract}
KOZLOWSKI ALEKSANDER ${ }^{1}$, KUKLA DAMIAN ${ }^{2}$
Experimental tests of steel unstiffened double side bolted end-plate joints have been presented. The main aim of the conducted tests was to check the behavior of joints in an accidental situation and possibility of creating secondary mechanism, i.e. catenary action in the scenario of column loss. Two types of end plate joints were tested: flush end-plate (FP) and extended end-plate (EP) with different thickness and different number of bolt rows in each. The tests were carried out on an isolated cross beam-column-beam type system until joint failure. During tests the available moment resistance and rotation capacity of bending joints and also values of tension forces in the beam were determined. The joints with extended end-plate have demonstrated higher bending and rotational capacity than flush end-plate. Significant deformation of column flanges, web and end plate were observed. The fracture of bolts was the failure mode of joints. Obtained results of axial force values in beam exceeded standard requirement what confirmed that the joints with unstiffened web column, flush or extended end-plate possess the ability of development the catenary action.

Keywords: double side steel joints, experimental test, beam-to-column connection, robustness, semi-rigid joints, column loss
\end{abstract}

\section{INTRODUCTION}

Two basic design situations: persistent and accidental should be considered during designing of frame structure. In a persistent situation (Fig. 1a) the frame loading is transferred through the entire system of appropriately connected columns and beam. In accidental situations (Fig. 1b), the column removal scenario may take place as a result of an explosion in the building, fire or impact of the vehicle. During a sudden change in the design situation from persistent to accidental, there is a significant change in the internal forces distribution in the system. This transformation is particularly noticeable in the area of direct column removal.

Distribution of forces in the internal connection (Fig. 2) is as follows: in persistent situation (Fig. 2a), the column is mainly subjected to the axial compression force, beams and joints are subjected to bending moment and shear forces. In accidental situation (Fig. 2b), the distribution of these forces changed significantly. The column in an accidental situation ceases to be support for the beam. In this case, the beams are forced to take over these additional vertical forces.

${ }^{1}$ Prof., DSc., PhD., Eng.,Rzeszów University of Technology, Faculty of Civil Engineering, ul. Poznańska 2,

35-084Rzeszów, Poland, e-mail: kozlowsk@prz.edu.pl,

${ }^{2}$ Master of Science, Rzeszów University of Technology, Faculty of Civil Engineering, ul. Poznańska 2,

35-084Rzeszów, Poland, e-mail: damian9105@,o2.pl 

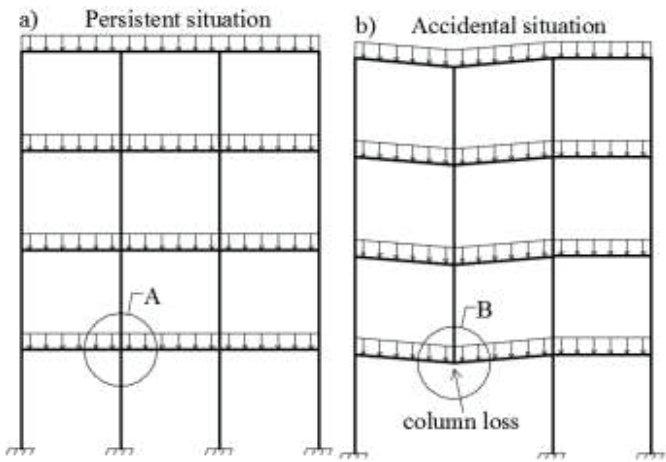

Fig. 1. Design situations of frame structures: a) persistent, b) accidental

The values, the sign of the bending moment and the shear force in the joint changed. Additional horizontal force in the beam axis also appeared. In accidental situation, the load value may significantly exceed the design elastic bearing capacity of the joint. This can lead to major deformations of connections or/and even to joint damage.

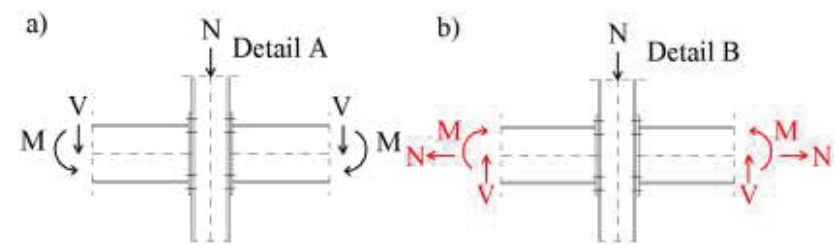

Fig.2.Configuration of force in connection: a) at persistent situation, b) at accidental situation of column loss

The aim of the paper is to test the behavior of connections in an accidental situation. The obtained test results should give the answer to the possibility of creating secondary mechanism, i.e. catenary action by developing the axial forces in the beams and joints. The developed catenary action can protect the steel structure against progressive collapse. The performed tests allow checking whether such type of joints can be used as bracing elements allowing for the appropriate structural connection of elements.

The comparison between the behavior of joints tested in the framework systems [24] and tested on isolated systems was presented. In both tests the same cross-sections of beams and column along with the geometry of the connections were used. The comparative analysis will provide information on the impact of connections size on the behavior of joints.

In accordance with the standard [11] building structure should be designed and performed in order not to be damaged in a way that is disproportionate to the initial cause during events such as explosion, impact and consequences of human errors. Possibility of damage should be avoided or limited by proper selection of one or several ways. As the structure is a set of interconnected parts designed to transfer loads and ensure adequate stiffness, the structural resistance should be provided to all structural elements as well as their connections according to [13].

The standard [12] considers two design strategies in accidental design situations presented in Fig. 3. 


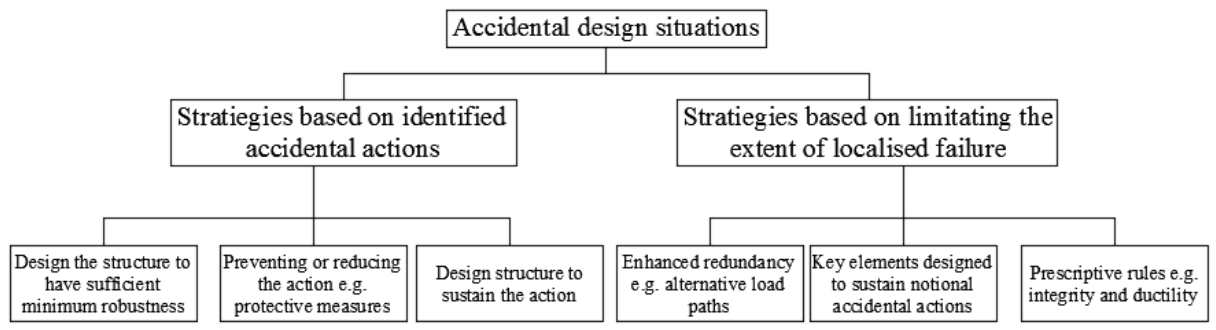

Fig.3.Strategies for accidental design situations [12]

Building should be classified to the appropriate consequence class. The standard distinguishes three classes: $\mathrm{CC} 1$ - low consequence of failure, $\mathrm{CC} 2 \mathrm{a}$ and $\mathrm{CC} 2 \mathrm{~b}$ - medium consequence of failure and CC3 - high consequence of failure. Choosing a given class determines the further course of action. For the consequence class $\mathrm{CC} 2 \mathrm{a}$ and $\mathrm{CC} 2 \mathrm{~b}$ it is ensured to use effective horizontal ties for frame and structural load-bearing walls, however for $\mathrm{CC} 2 \mathrm{~b}$, it is recommended to use vertical ties in all supporting columns and walls.

Horizontal ties in framed structure should be provided around the perimeter of each storey floor and roof level and internally in two right angle directions in order to tie the column as well as wall elements to the structure of the building [12]. Each continuous tie and its connection must be capable of transferring the design tensile load in the event of an extreme limit state:

$$
\begin{array}{ll}
\text { For internal ties } & T_{i}=0,8\left(g_{k}+\psi q_{k}\right) s L \text { or } 75 \mathrm{kN} \\
\text { for perimeter ties } & T_{p}=0,4\left(g_{k}+\psi q_{k}\right) \text { sLor } 75 \mathrm{kN}
\end{array}
$$

where:

$\mathrm{g}_{\mathrm{k}}$ - dead load, $\mathrm{qk}$ - live load, $\psi$ - coefficient of combination, $\mathrm{s}$ - spacing of the ties, L- span of the ties.

The use of steel with appropriate ductility results in significant plastic deformation in the structure. This enables the redistribution of forces, i.e. the transfer of excessive load to less-loaded parts what prevents the sudden destruction of members and/or connections.

The progressive collapse phenomenon is also defined in British [2] and American [6,18] standards. To mitigate the progressive collapse, standards DoD [6] and GSA [18] recommend using the alternative load path method. Due to the creation of an alternative load path, a redistribution of the applied loading from the damaged part to the remaining undamaged elements takes place. Local damage does not lead to the development of a ,domino" effect and further collapse is stopped.

In recent years, there has been a significant increase in interest in the robustness of steel frame systems. Previous experimental and computer analysis of steel joints, two- and three-dimensional framed systems is presented in Table 1. 
Table 1.Comparison of connections and steel structure tests

\begin{tabular}{|c|c|c|c|c|c|}
\hline $\mathrm{N}^{\mathrm{o}}$ & Author & Country & Type of tests & $\begin{array}{l}\text { Referen } \\
\text { ce }\end{array}$ & Year \\
\hline 1 & $\begin{array}{l}\text { Barata P., Santiago } \\
\text { A.,Riguerio C., Rodrigues } \\
\text { J. P. }\end{array}$ & Portugal & $\begin{array}{l}\text { Experimental tests of steel bolted end plate joints } \\
\text { subjected to impact loading }\end{array}$ & {$[1]$} & 2015 \\
\hline 2 & Cortes G., Liu J. & Switzerland/USA & $\begin{array}{l}\text { Experimental study of a two-dimensional steel } \\
\text { frame with various types of bolt connections }\end{array}$ & [3] & 2017 \\
\hline 3 & $\begin{array}{l}\text { D'Antimo M., Latour M., } \\
\text { Rizzano G., Jaspart J-P., } \\
\text { Demonceau J-F. }\end{array}$ & Belgium/Italy & $\begin{array}{l}\text { Experimental tests of steel end plate joints with } \\
\text { the use of friction pads }\end{array}$ & [4] & 2018 \\
\hline 4 & $\begin{array}{l}\text { Dinu F., Marginean I., } \\
\text { Dubina D. }\end{array}$ & Romania & $\begin{array}{l}\text { Experimental tests of two-dimensional steel } \\
\text { frame system with } 4 \text { types of bolt connections }\end{array}$ & [7] & 2017 \\
\hline 5 & $\begin{array}{l}\text { Dinu F., Marginean I., } \\
\text { Dubina D., PertanI. }\end{array}$ & Romania & $\begin{array}{l}\text { Experimental tests of a steel 3D frame with end } \\
\text { plate joints }\end{array}$ & {$[8,9]$} & 2016 \\
\hline 6 & $\begin{array}{l}\text { Giżejowski M., Szwed A. } \\
\text { Saleh A.A.K., Barcewicz } \\
\text { W. }\end{array}$ & Poland & $\begin{array}{l}\text { Experimental tests of a two-dimensional frame } \\
\text { system with steel and composite steel-composite } \\
\text { structure with bolted end plate joints }\end{array}$ & {$[17,24]$} & 2013 \\
\hline 8 & $\begin{array}{l}\text { GiżejowskiM.A., } \\
\text { Kwaśniewski L., Saleh } \\
\text { B., Balcerzak M. }\end{array}$ & Poland & $\begin{array}{l}\text { Numerical Study of Joints behavior for } \\
\text { Robustness Assessment }\end{array}$ & [16] & 2012 \\
\hline 9 & $\begin{array}{l}\text { Kozłowski A., Giżejowski } \\
\text { M., Sleczka L., Pisarek } \\
\text { Z., Saleh B. }\end{array}$ & Poland & $\begin{array}{l}\text { Experimental tests of a two-dimensional frame } \\
\text { system with steel and composite steel-composite } \\
\text { structure with bolted end plate joints }\end{array}$ & [19] & 2011 \\
\hline 10 & $\begin{array}{l}\text { Kuhlmann U. Rolle L. } \\
\text { Jaspart J.-P. ,Demonceau } \\
\text { J.-F. at all }\end{array}$ & $\begin{array}{l}\text { Germany/Belgium } \\
\text { /Luksemburg/ } \\
\text { Italy }\end{array}$ & $\begin{array}{l}\text { Experimental tests of a bolted connections, a two- } \\
\text { dimensional frame system with a composite } \\
\text { structure }\end{array}$ & {$[20]$} & 2009 \\
\hline 11 & $\begin{array}{l}\text { Li H., Cai X., Yhang Y., } \\
\text { Yhang B., Wang W. }\end{array}$ & China & $\begin{array}{l}\text { Experimental tests of a 3D frame with welded } \\
\text { joints }\end{array}$ & [21] & 2017 \\
\hline 12 & $\begin{array}{l}\text { Meng B., Zhong W., Hao } \\
\text { J }\end{array}$ & China & $\begin{array}{l}\text { Experimental tests of a two-dimensional frame } \\
\text { system with various span ratio }\end{array}$ & [22] & 2018 \\
\hline 13 & $\begin{array}{l}\text { Prinz G. S., Nussbaumer } \\
\text { A., Borges L., Khadka S. }\end{array}$ & $\begin{array}{l}\text { USA/Switzerland, } \\
\text { Portugal/Nepal }\end{array}$ & Experimental tests of end plate joints & [23] & 2014 \\
\hline 14 & $\begin{array}{l}\text { Song B. I., Giriunas K. } \\
\text { A., Sezen H. }\end{array}$ & USA & $\begin{array}{l}\text { Experimental tests of a steel building with a } \\
\text { frame structure }\end{array}$ & {$[25,26]$} & 2013 \\
\hline 15 & Yang B., Tan K. H. & China/Singapur & Experimental tests of steel bolted connections & [28] & 2013 \\
\hline
\end{tabular}

Experimental tests on a single-storey spatial frame with end-plate joints and a central unsupported column are presented in $[8,9]$. Structure and connections have shown very good behavior and adequate resistance to transfer the catenary action. Experimental tests [21] of the 3D frame with welded main joints and bolted secondary joints subjected to the situation of losing the internal column were performed. Tests have shown that catenary action plays a key role in the load capacity of the system. During the test, in the beams in compliance with the main axis, horizontal forces equal to $78 \%$ of the load capacity of the beam were created, whereas in secondary beams equal to $12 \%$ of the load capacity. The reason for this difference was different joints stiffness.

The experimental test on an existing building with a steel framed structure was presented in [25, 26]. During the test four parts of various columns were removed. The gradual cutting of columns caused an increase in deformations and deflections. The removal of four columns from the structure did not cause the building collapse.

Static tests of two-dimensional two-span steel frames with four types of steel joints and unsupported central column are shown in [7]. The welded cover plate flange connections (CWP) proved to be the most resistant due to their high rotational capacity and thus the possible development of catenary action. 
Two-dimensional steel frames with two spans with welded-bolted joints were tested in the experiment [22]. The influence of the ratio of the span's length on the behavior of the frame was tested. Test observations show that frames with smaller spans' length showed better load carrying capacity. In the studies three phases: elastic, elastic-catenary and catenary were observed. In the initial phase, compression in the beams was observed, then the tension occurred.

In the paper [3] experimental tests of twelve steel two-dimensional double-span symmetrical frames with various beam-to-column connections were performed. Traditional connections were used and also improved connections were proposed. The double angle connection turned out to be the best of the traditional connections. Conventional connections were damaged by rupture of the bolts. Improved connections achieved higher load capacity for vertical load, greater rotation capacity and development of catenary action. Modification of these connections has also changed the model of connection destruction.

The analysis of the behavior of two-dimensional frame systems with steel and composite steel and concrete structure in the situation of the middle column removal was presented in $[15,19,24]$. The tests have shown that the steel system with the extended end-plate connections exhibits greater resistance to the progressive collapse despite the lower ductility. These joints are characterized by a better balance between bearing capacity and the ability to rotate.

Experimental investigations of seven types of different connections in a two-span flat system were presented in paper [28]. Connections were divided into two groups: pinned and semi-rigid. Combination of top and seat with web angle (TSWA) with $12 \mathrm{~mm}$ angles turned out to be the best combination in terms of load capacity. Each of the connections showed the ability to develop the catenary action, thereby increasing the load capacity of the system. In order to ensure the proper resistance of the structure, it is necessary to design joints carrying significant tensile forces after reaching high rotations.

In the experimental studies presented in [23] one-sided end-plate joints with thick end plates (30 $\mathrm{mm}$ ) and many bolts in the rows ( 2 or 4 bolts) were tested. Extended end-plate or flush end-plate joints were used. The test results showed that the highest load-bearing capacity is achieved by extended end-plate with four bolts in a row. The lowest load capacity has been obtained for a flush plate with 2 bolts in a row. The use of thick end plates and 4 bolts in a row significantly reduces the ability of the rotation of the connection. The comparison of the load capacity obtained in the test with the calculation of the moment resistance of the connection by the component method showed an underestimation of the load capacity of $27 \%$ to disadvantage of the component method.

The behavior of end-plate joints with thin plate applied in steel and composite steel and concrete structure was presented in [15]. Four specimens in a cross beam-column-beam system were tested. As part of the FREEDAM [4] project, experimental tests of a new type of end-plate joint were made. This connection was mainly characterized by the use of friction pads to increase the rotation of the joint after obtaining the appropriate load capacity. The behavior of this connection can be divided into three phases: elastic, slip and phase growing up to the moment of failure. This connection has obtained significant energy dissipation with high rotational capacity.

The quasi-static and impact tests of the flush end-plate joint have been presented in [1]. The impact load causes a slight increase in the moment resistance at a similar angle of rotation compared to 
static tests. In the initial phase of the test, the impact load increases the stiffness of the joint, which may be due to the redistribution of internal stresses in the joint.

Six joints with flush end plate were tested in the frame of project [20]. The tests on isolated parts of the structure in a cross beam-column-beam system were carried out. The research focused on the influence of the end plate thickness and bolt spacing on the behavior of joints. The first groups of tested joint was specimens with end plates thickness of 6, 9, 12 and $16 \mathrm{~mm}$. In the second group, the bolt spacing was changed with the same thickness of the end plate $(12 \mathrm{~mm})$. Based on the experimental tests, it was found that the thicker end plate the bigger moment resistance of the connection. Increasing the thickness of the plate, however, causes a decrease in the rotation capacity of the joint. In the case of connections of the same thickness of end plates, changing the bolt spacing significantly influences the behavior of connections. Reducing the vertical spacing of the bolts decreases the load capacity of the joint, but increases the rotation. This is due to the greater possibility of deformation of the plate and the formation of a membrane effect.

As above presented experimental research has shown, the use of rigid connections is an inappropriate approach. Although these joints have a higher bending moment resistance, they have lower rotational capacity. A small rotation of the connection does not allow for the creation of a catenary action desired in the event of an accidental situation, such as a column loss. The catenary action plays a significant role in the final phase of the loading by increasing the resistance of the structure against collapse.

Building structure except for meeting the basic conditions ultimate limit state and serviceability limit state should also be characterized by adequate robustness. Robustness [27] determines the ability of the structure to create various possible scenarios that would cause the structure to survive without collapse. One of these scenarios is the alternative load path. This approach is characterized by the ability of the structure to transfer additional loads from damaged elements and redistribute them to undamaged elements. In this approach, the load is distributed mainly at the part of the direct column removal. In order to be able to run an alternative load path, the structure must have the appropriate, properly designed connection of structure members.

\section{EXPERIMENTAL TESTS OF ISOLATED END PLATE CONNECTIONS}

\subsection{SPECIMENS}

The tested specimen (Fig. 4) is an isolated part of a frame structure in a cross beam-column-beam arrangement. The beams are designed of IPE 300 profile with a total length of $965 \mathrm{~mm}$, a HEB 200 column with a total length of $870 \mathrm{~mm}$. The beams elements were made using remaining parts of beams used in the tests [24]. The length of the beam corresponded to the place of zeroing of bending moments in a frame with a length of $6.0 \mathrm{~m}$ spans in a combination of gravitational loads. The total length in the support axes is $1890 \mathrm{~mm}$. The connection were designed as end-plate joints with flush or extended end plate. The end plate was designed with three variants of thickness: 10, 15 and $20 \mathrm{~mm}$ for both types of plate. The connection was made by M20 bolts $10.9 \mathrm{HV}$ with two bolts in a row. 


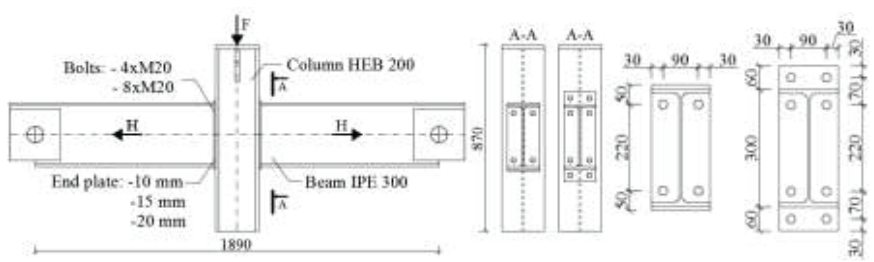

Fig. 4. Specimen scheme and details of connections (dimensions are in $\mathrm{mm}$ )

A different number of bolt rows were also used (Fig. 4): two rows of bolts for a flush end-plate, four rows of bolts for the extended end-plate joints. At the end of the beams there are additionally two-sided plates strengthening the beam web with dimensions $240 \times 240 \mathrm{~mm}$ and a thickness of 20 $\mathrm{mm}$. The purpose of these plate was to avoid deformation of the web under the influence of high vertical and horizontal forces, which could lead to the ovalization of the hole. In order to connect the specimen to the test stand, round holes $80 \mathrm{~mm}$ in diameter were designed at the ends of the beams. In the upper part of the column, a 200x200 mm rectangular plate $20 \mathrm{~mm}$ thick was designed to distribute the linear load from the oil jack to the entire cross-sectional area of the column. Under the plate in the axis of the column, $20 \mathrm{~mm}$ thick stiffener was designed to strengthen the web at the point of application of the load. Table 2 presents the geometrical parameters of the specimen tested.

Table2.Collection of geometrical parameters of specimens

\begin{tabular}{|c|c|c|c|c|c|c|}
\hline Specimen & Beam & Column & End plate & Plate thickness & Bolt size & Bolts rows \\
\hline P-1 & IPE 300 & HEB 200 & Flush & $10 \mathrm{~mm}$ & M20 & 2 \\
\hline P-2 & IPE 300 & HEB 200 & Flush & $15 \mathrm{~mm}$ & M20 & 2 \\
\hline P-3 & IPE 300 & HEB 200 & Flush & $20 \mathrm{~mm}$ & M20 & 2 \\
\hline P-4 & IPE 300 & HEB 200 & Extended & $10 \mathrm{~mm}$ & M20 & 4 \\
\hline P-5 & IPE 300 & HEB 200 & Extended & $15 \mathrm{~mm}$ & M20 & 4 \\
\hline P-6 & IPE 300 & HEB 200 & Extended & $20 \mathrm{~mm}$ & M20 & 4 \\
\hline
\end{tabular}

\subsection{TEST SETUP}

Figure 5 shows the view of the test setup. The test stand consisted of two columns bolted to the laboratory floor with the additional use of diagonal braces on the outside. Connection of the stand column with a beam specimen was designed as pinned with $78 \mathrm{~mm}$ diameter of pin, with full rotation capability in the specimen plane. The lower part of the column specimen was supported laterally to protect the column of inclination from the plane of the specimen. The horizontal stiffness in the plain of tested specimen of the test stand shown in Fig. 5 obtained from the tests was equal to $225 \mathrm{kN} / \mathrm{mm}$. 
a)

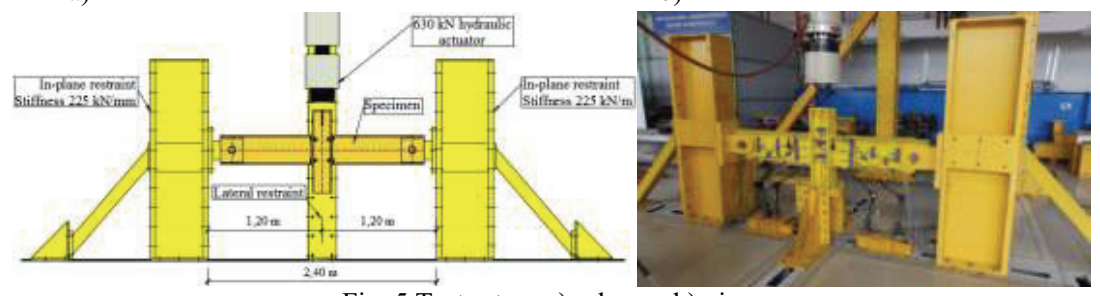

Fig. 5.Test setup: a) scheme, b) view

\subsection{TEST INSTRUMENTATION}

Load was applied to the upper surface of column by the INSTRON $630 \mathrm{kN}$ hydraulic jack through a round roller in the column axis. A teflon foil spacer was additionally applied to the top surface of the end plate of the column. Two steps of each specimen loading were executed: the initial one consisting in a small load on the specimen in order to check the operation of the instrumentation and the proper fitting of the connection parts, the second step is the basic loading. The basic loading was divided into two stages: the first used a constant displacement increase of $0.5 \mathrm{~mm}$ per minute during 60 minutes, then a displacement of $2.0 \mathrm{~mm}$ per minute was established till the end of the test. Seventeen strain gauges with $120 \Omega$ resistance with temperature compensation were instrumented in order to measure strains at selected locations on the surface of the specimen. Seven strain gauges were fixed on each side of the beams, three of them are located in the main axis of the beam, the other four in the vicinity of the joint at the height of the flange. Three strain gauges were fixed to the column web in the main axis of the column at the height of the flange and beam axes. The test also involved six displacement transducers LVDT in two arrangement. Four transducers were used to measure deflection at selected places in the specimen in the vertical direction. Two transducers were used to measure horizontal displacements of supports during the test. Moreover, two inclinometers to measure directly the rotation angle of beams and one to the column were applied. The layout of arrangement of stain gauges, displacement transducers and inclinometers is presented in Fig. 6.

a)

b)

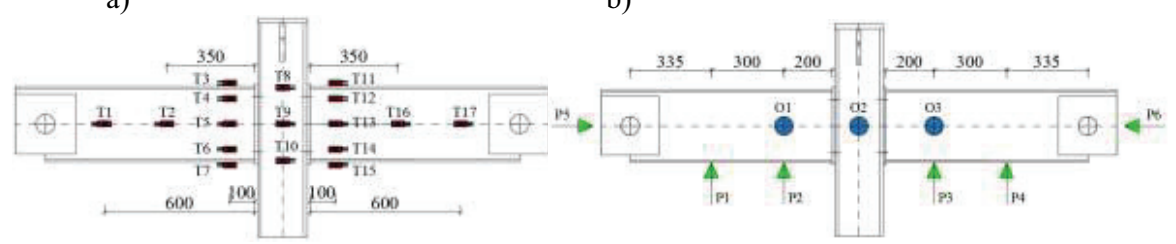

Fig. 6.Layout: a) strain gauges, b) displacement transducersand inclinometers

\subsection{MECHANICAL CHARACTERISTICS OF THE MATERIALS}

In order to evaluate the material parameters of each of the steel used to make the specimens, three material coupon were cut out (Fig. 7). 
a)

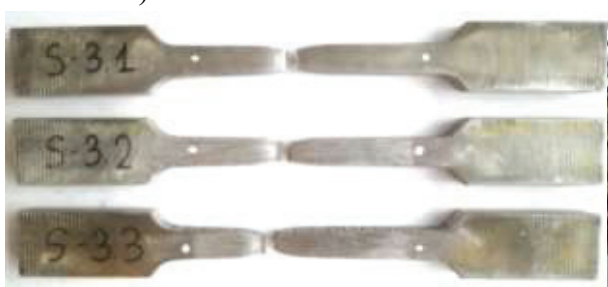

Fig. 7.View: a)material coupon after test, b) bolt after test b)

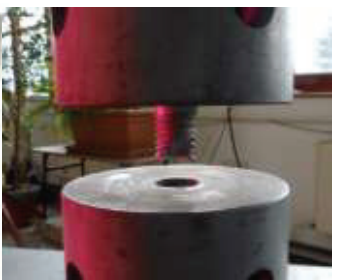

Static tensile coupon test in the INSTRON $1200 \mathrm{kN}$ testing machine of specimens was conducted. During test, an optical extensometer was used to measure longitudinal deformation of the sample. Strength testing also included bolts. In table 3 the yield point $f_{y}$, tensile strength $f_{u}$, maximum elongation $A_{g}$ were collected. Table 3 also shows the fracture strength $f_{\mathrm{f}}$ (engineering stress) and total elongation at the maximum stress $\mathrm{A}_{\mathrm{gt}}$.

Table3.Average characteristics for steel plates, members and bolts

\begin{tabular}{|c|c|c|c|c|c|}
\hline Element & $\mathrm{f}_{\mathrm{y}}\left[\mathrm{N} / \mathrm{mm}^{2}\right]$ & $\mathrm{f}_{\mathrm{u}}\left[\mathrm{N} / \mathrm{mm}^{2}\right]$ & $\mathrm{f}_{\mathrm{f}}\left[\mathrm{N} / \mathrm{mm}^{2}\right]$ & $\mathrm{A}_{\mathrm{gt}}[\%]$ & $\mathrm{A}_{\mathrm{g}}[\%]$ \\
\hline End plate, $\mathrm{t}=10 \mathrm{~mm}$ & 295 & 418 & 300 & 0.21 & 0.32 \\
\hline End plate, $\mathrm{t}=10 \mathrm{~mm}$ & 396 & 522 & 357 & 0.14 & 0.29 \\
\hline End plate, $\mathrm{t}=10 \mathrm{~mm}$ & 263 & 406 & 291 & 0.15 & 0.36 \\
\hline Column HEB 200 & 257 & 414 & 285 & 0.18 & 0.35 \\
\hline Beam IPE 300 & 305 & 420 & 342 & 0.20 & 0.32 \\
\hline Bolt, M20 class 10.9 HV & 1005 & 1116 & - & - & 0.12 \\
\hline
\end{tabular}

\section{EXPERIMENTAL RESULTS}

\section{FLUSH END-PLATE CONNECTION}

\subsection{P-1 SPECIMEN - 10 MM THICK END PLATE}

The force-deflection relationship of the specimen P-1 is shown in Figure 8a. The vertical F load (Fig. 4) is the loading applied to the top surface of the column by a hydraulic jack and measured during tests in the form of a digital reading. In the initial phase of the study, a linear increase of vertical $\mathrm{F}$ load to a value of approximately $150 \mathrm{kN}$ was observed. After exceeding this value, the load increment began to decrease, where in the final phase the vertical displacements increased 
significantly without any visible change in loading. The graph (Fig.8a) also shows the development of horizontal axial $\mathrm{H}$ force in beams which have been obtained on the basis of measurements of the strain gauges. For the left beam, the value of $\mathrm{H}$ force has been determined from the strain reading of the T5 strain gauge, for the right beam with the T13 strain gauge. From the beginning of the loading, significant increases in the horizontal $\mathrm{H}$ force were observed. Up to value of vertical displacement of $10 \mathrm{~mm}$, the increase in $\mathrm{H}$ force for left and right beam was almost the same. After exceeding $10 \mathrm{~mm}$ of deflection in the beams a difference in the value of $\mathrm{H}$ force started to arise, nevertheless the axial force in both beams shows a continuous increase from the beginning to the end of the test. Catenary action in the beams was developed. The basic characteristic of connection behavior, namely the $M$ bending moment - $\varphi$ rotation diagram was shown Fig. 8b. In the initial phase of the loading, a constant linear increase in the bending capacity of the joint was observed, which is identical with the constant initial stiffness of the joint. After obtaining the bending moment of $67 \mathrm{kNm}$ by the right connection and bending moment of $85 \mathrm{kNm}$ by the left connection the bending moment in the connections began to decrease. In the final phase of the test, there was a significant increase in the rotation of the joint with a decrease in the bending moment of the joints.

a)

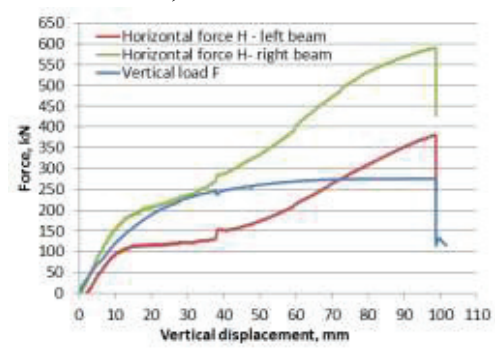

b)

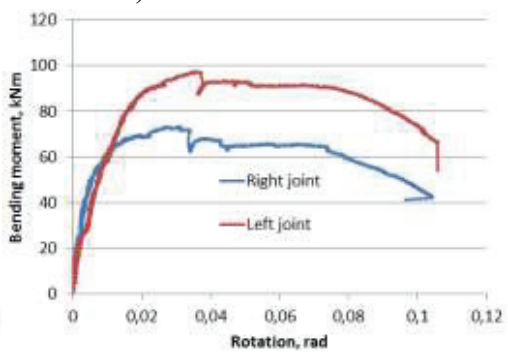

Fig. 8.P-1 specimen: a) vertical load and horizontal force vs. vertical displacement, b) bending moment vs. joint rotation

During the test, noticeable deformations of part of the joint were observed. The end plates near the bottom row of bolts, i.e. in the tensile zone have been the first elements that were deformed. With the increase of the loading, the deformation of the end plate increased. There were also deformations of the flanges and column web at the height of the beam flange (Fig.9a). Further increase in loading caused the development of further deformations. The specimen was failed by violent bolts' fracture in the bottom row (Fig. 9b). After the test, one could notice a clear buckling of the column's web from its surface. This phenomenon is caused by the action of compressive forces in connection at the height of the upper beam flange (Fig.9c). In the tensile zone, bends of the column flange was visible due to the tensile forces transmitted by the bolts of the lower row of the connection. During the test, it was possible to notice the opening of the contact at the height of the beam's axis. 
a)

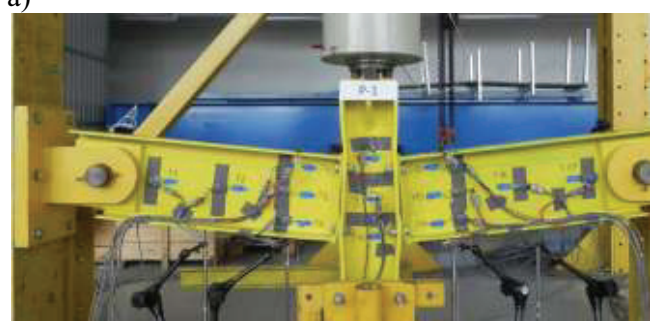

b)

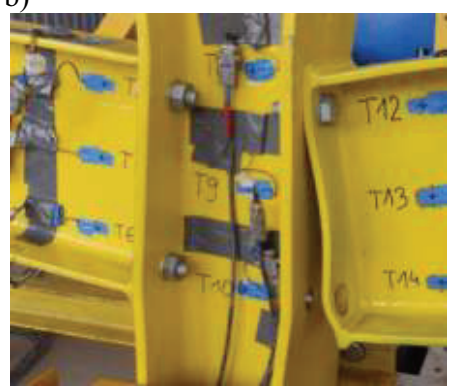

c)

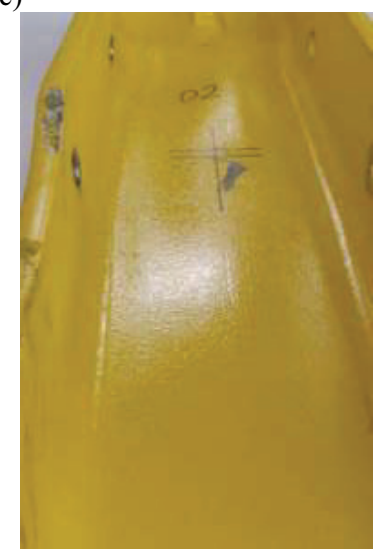

Fig. 9. P-1 specimen: a) view before failure, b) failure mode of specimen, c) column view after test

The distribution of strains in the P-1 specimen were shown in Fig. 10a-c. The strain gauges located on the beam flanges (T3, T7 and T11, T15) showed a linear increase in strain during the whole test. Strain gauges set in the horizontal axis of the beam (T1, T2 and T5 as well as T13, T16 and T17) showed different values. The T1, T2 and T16 and T17 strain gauges have been compressed, while the $\mathrm{T} 5$ and $\mathrm{T} 13$ strain gauges near the joint were tensioned.

a)

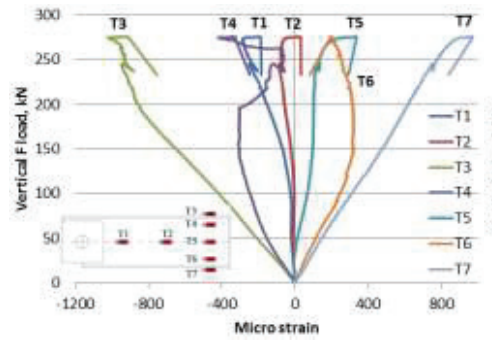

b)

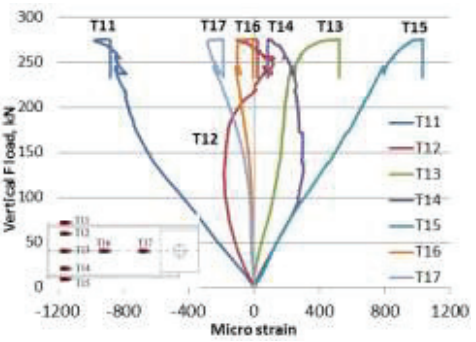

c) 


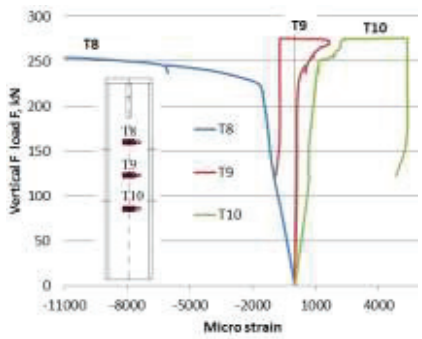

Fig.10. Strain distribution of P-1 specimen: a) left beam, b) right beam, c) column

The column strain (Fig. 10c) show different values. The strain gauge set at the height of the upper beam flange $\mathrm{T} 8$ to the value of $220 \mathrm{kN}$ showed a linear increase. After exceeding this value, there was a significant increase until it was broken. The middle of the T9 column strain gauges had a negligible deformation value up to the force of $230 \mathrm{kN}$. Then it was compressed, while in the final phase the mark changed to tension. The T10 strain gauge till a force of $250 \mathrm{kN}$ showed a constant increase in strain, where in the final phase there was a significant increase in value. All three strain gauges represent the respective web zones in the connection: T8 is the compression zone, T9 is the neutral zone and $\mathrm{T} 10$ is the tensile zone.

\subsection{P-2 SPECIMEN - 15 MM THICK END PLATE}

From the beginning of the P-2 specimen test, there was a constant vertical load increase to the value of about $200 \mathrm{kN}$ (Fig.11a). A further increase in vertical displacement followed a decrease in the increment of vertical force. At a deflection of $40 \mathrm{~mm}$, a further increase of $\mathrm{F}$ force was lost until the moment of destruction. The development of the horizontal axial force in the beams was almost constant during the study. The axial $\mathrm{H}$ force was the same in both beams. Connection behavior is shown in Fig. 11b. In the initial phase, the increase in the load capacity of the joint was linear. After exceeding $60 \mathrm{kNm}$, the rotation of the connection started to increase. After exceeding the rotation of connections 0,04 radian, the moment in the connections started to drop until the end of the test.

a)

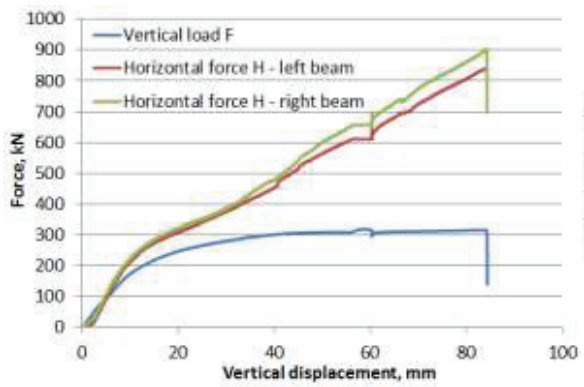

b)

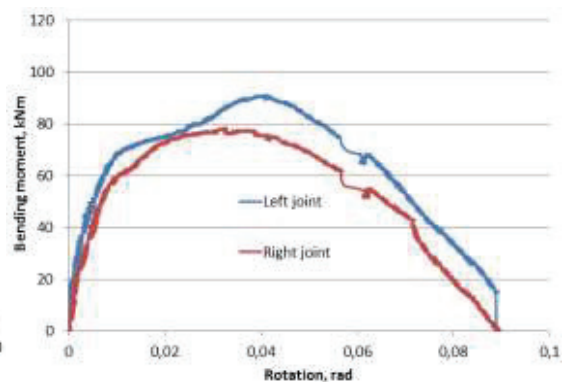

Fig.11. P-2 specimen: a) vertical load and horizontal force vs. vertical displacement, b) bending moment vs. joint rotation 
In the initial phase of the test, no signs of deformation of the specimen were noticed. After reaching loading around $200 \mathrm{kN}$, deformation of the column flanges started to appear. The column flanges at the height of the upper bolt rows began to move towards the main axis of the column. The column flanges at the level of the lower row of bolts moved in the opposite direction. The increase in loading caused further development of deformation of the column section (Fig. 12a). The end plate (Fig. 12b), despite the same thickness as the column flanges, has been not deformed. After the test (fig. 12c), buckling of the column web at the level of the upper row of the bolts was also noticed. Failure mode of the specimen was the rupture of the bolts in the bottom row.

a)
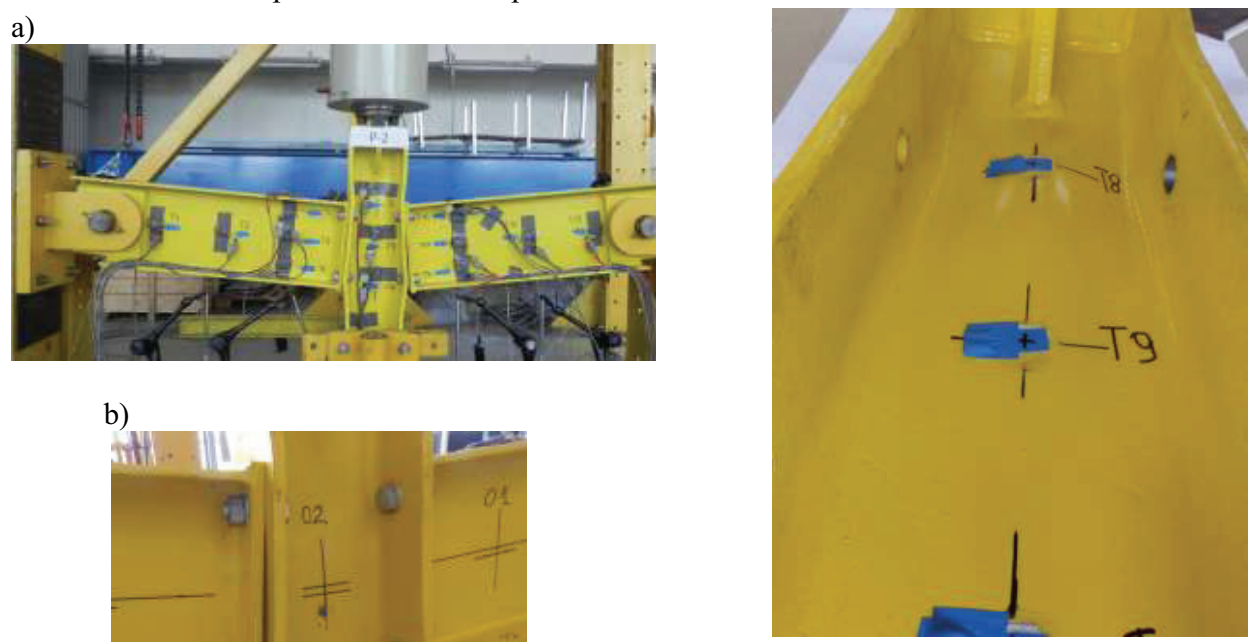

b)

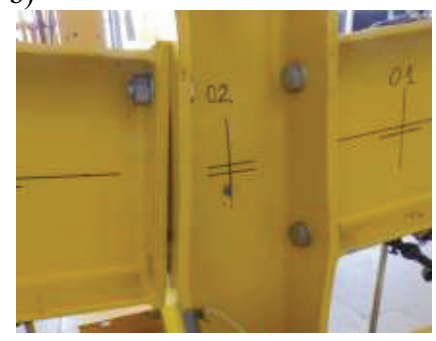

Fig.12. P-2 specimen: a) view before failure, b) failure mode of specimen, c) column view after test Strains of the P-2 specimen are shown in Fig. 13. As in the P-1 specimen, the largest strains occurred in the beam flanges (T3, T7 and T11 and T15) (Fig. 13a and b). A significant increase in stain in the upper part of the beam web T4 and T12 is visible after reaching F force of $200 \mathrm{kN}$. This indicates the appearance of considerable compressive forces in this zone of the beam.

a)

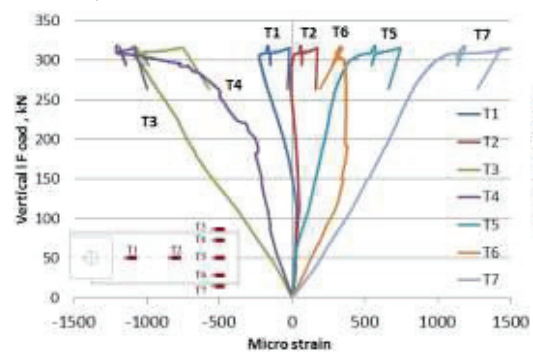

b)

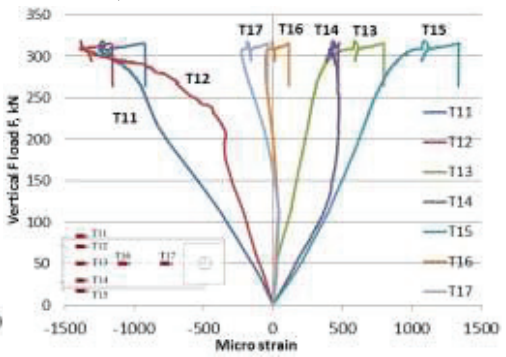


c)

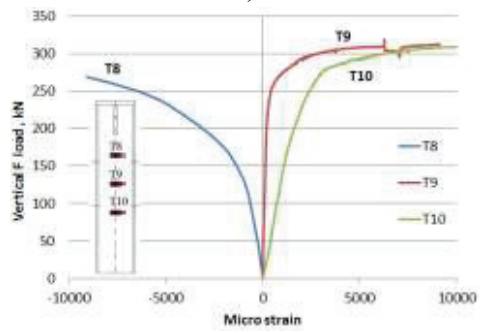

Fig.13. Strain distribution of P-2 specimen: a) left beam, b) right beam, c) column

The web column behavior during the test can be divided into several phases. In the initial phase of the test, three zones can be clearly seen: the compression zone represented by the T8 strain gauge, the neutral zone represented by T9 and the tensile zone by T10. After exceeding the force of 250 $\mathrm{kN}$, there was a change from three to two zones: compression represented by $\mathrm{T} 8$ strain gauges and tensioned by $\mathrm{T} 9$ and $\mathrm{T} 10$.

\subsection{P-3 SPECIMEN - 20 MM THICK END PLATE}

From the beginning of the test (Fig. 14a) to about $200 \mathrm{kN} \mathrm{F}$ vertical loading, the specimen showed a linear loading increase. After exceeding $200 \mathrm{kN}$ there was a decrease in the growth of the vertical $\mathrm{F}$ load, where it was almost invisible after reaching the $\mathrm{F}$ value of $300 \mathrm{kN}$. In the final phase of the test, only a large increase in displacements was observed. The jump at the curve of vertical load at the value of $300 \mathrm{kN}$ was caused by operator error. The development of horizontal $\mathrm{H}$ axial force in beams is shown in Figure 14a. From the beginning of the study, the tensile $\mathrm{H}$ force in both beams was developed. During the study connection behavior (Figure 14b) was variable. In the initial phase of the loading a linear increase of bending moment was observed. Then, after exceeding $60 \mathrm{kNm}$, there was a decrease in stiffness caused by the plasticization of the connection elements. After exceeding the rotation of connections equal to 0.05 radians there was a significant linear decrease in of the moment in the connections.

a)

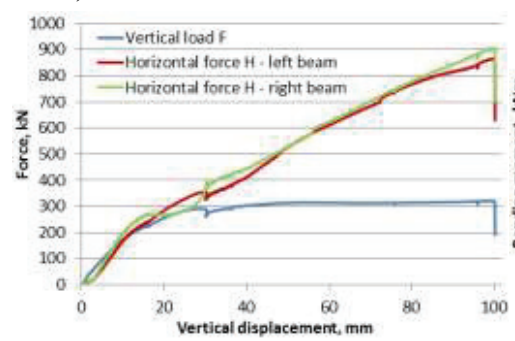

b)

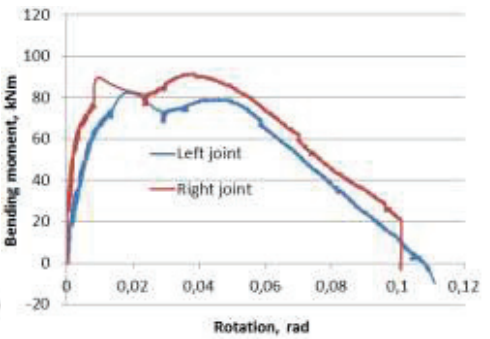

Fig.14. P-3 specimen: a) vertical load and horizontal force vs. vertical displacement, b) bending moment vs. joint rotation 
From the beginning of the test, no visible deformation were observed till achieving a loading equal to $185 \mathrm{kN}$. After exceeding the load of $185 \mathrm{kN}$, the opening of the contact was observed at the bottom of the connection, which increased along with the loading increase. During the test, the largest deformation (Fig. 15a) was observed in column flanges in the zone of the lower row of bolts as well as the column and web flanges at the height of the upper beam flange. After the test, a significant deformation (buckling) of the column web was observed (Fig. 15c). This phenomenon arose as a result of the action of large compressive forces near the upper row of bolts. The specimen was damaged by fracture of the bolts in the bottom row. The bolts' fracture in the bottom row caused the damage of the joints.

a)

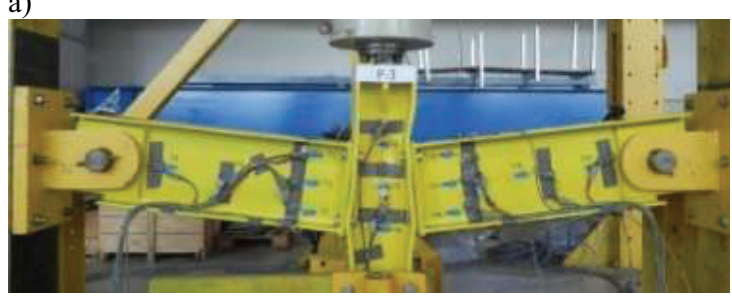

b)
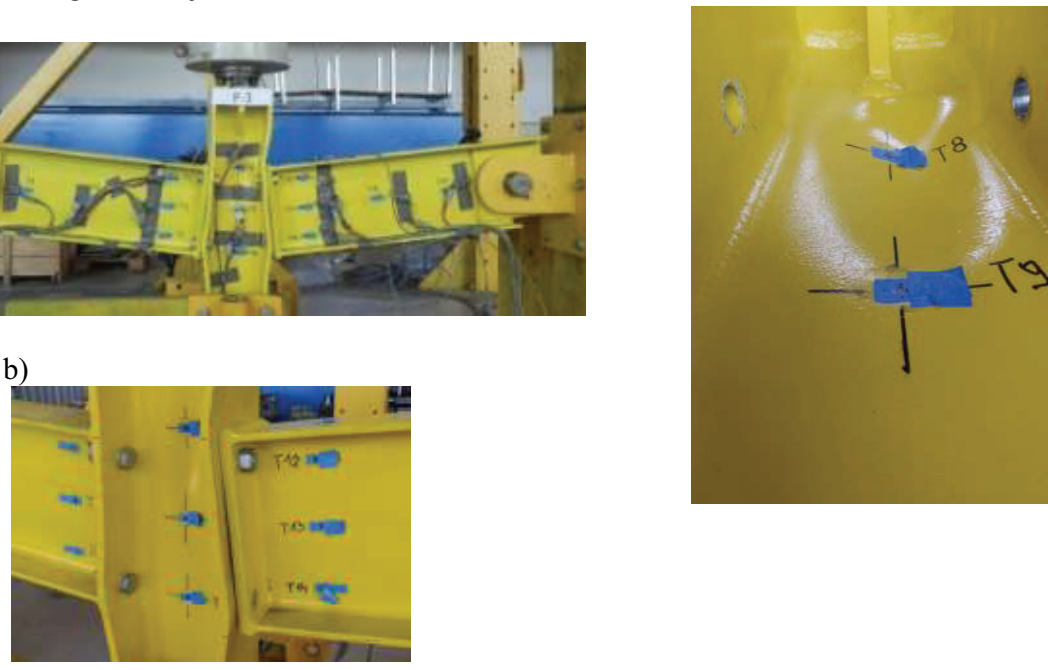

Fig.15. P-3 specimen: a) view before failure, b) failure mode of specimen, c) column view after test

The strains distribution of the P-3 specimen beams are shown in Fig. 16a and b. Practically all of the measurement points showed a linear increase in strain up to $310 \mathrm{kN}$ loading. After exceeding the loading of $310 \mathrm{kN}$, the tension strain increased and the strains in compression zones decreased. Interestingly, each of the strain gauges set in the main axis of the beam (T1, T2 and T5 as well as T13, T16 and T17) showed different values.

a)

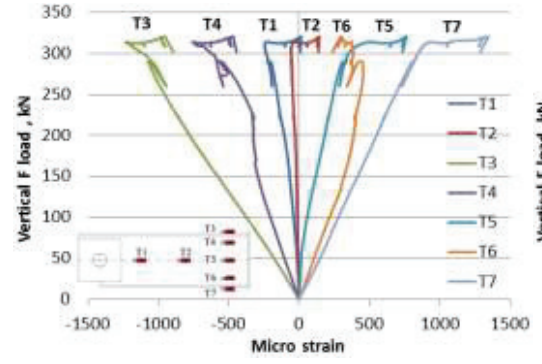

b)

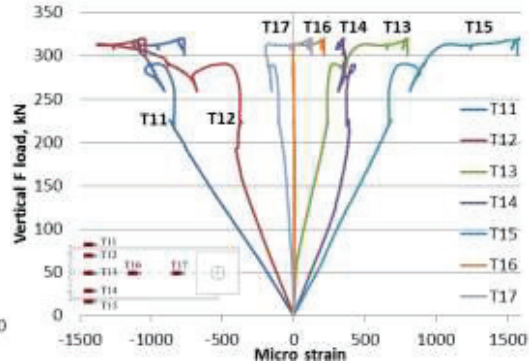


c)

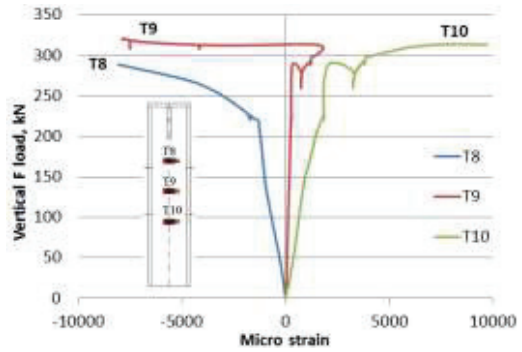

Fig.16. Strain distribution of P-3 specimen: a) left beam, b) right beam, c) column

In the initial phase of the loading the strain distribution in the column web (Fig.16c) can be divided into three zones. The compression zone is represented by aT8 strain gauge, tensioned over T10 and neutral by T9. However, after exceeding the $310 \mathrm{kN}$ loading, there was a reduction from three to two zones as it was in the P-2 specimen.

\section{EXTENDED END-PLATE CONNECTION}

\subsection{P-4 SPECIMEN -10 MM THICK END PLATE}

From the beginning of the test (Fig. 17a) to $\mathrm{F}$ load of about $200 \mathrm{kNa}$ constant linear increase of loading was observed. After exceeding $200 \mathrm{kN}$, non-linearity begun and specimen deformations started to be visible. After reaching approximately $30 \mathrm{~mm}$ of specimen deflection, the load $\mathrm{F}$ increase was small. The horizontal axial force $\mathrm{H}$ in the beams showed different values during the test. Up to $20 \mathrm{~mm}$ vertical displacement of the specimen, the forces were compression. Then, the tensile force developed with a linear increase until the end of the test. The behavior of connections were shown at the M- $\Phi$ curve (Fig. 17b). The initial phase shows a linear increase of bending moment in the joint. After reaching $120 \mathrm{kNm}$, there was an increase in rotation with a smaller increase in bending moment. After obtaining the rotation of connections, 0.03 radians in joints there was a linear decrease of the bending moment until the end of the test.

a)

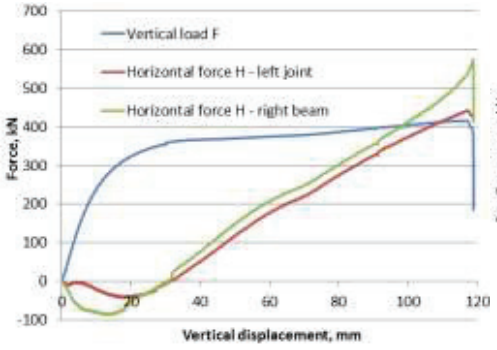

b)

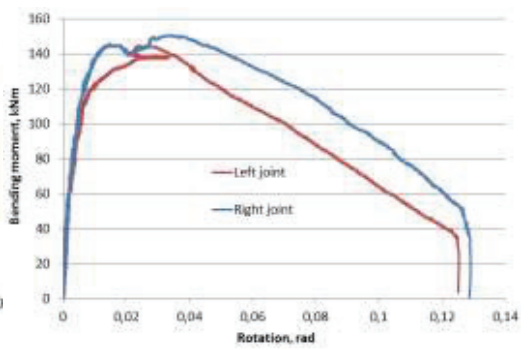

Fig.17. P-4 specimen: a) vertical load and horizontal force vs. vertical displacement, b) bending moment vs. joint rotation 
In the initial phase of the test, up to approximately $200 \mathrm{kN}$ no visible changes in the specimen geometry were observed. After exceeding $200 \mathrm{kN}$, the deformations of the column flanges in the tensile zone started to appear. At about $330 \mathrm{kN}$, deformations of the column flanges in the compression zone of the joint started to develop (Figure 18a). After exceeding $350 \mathrm{kN}$, fracture of the weld (Fig.18b) connecting the end plate in the bottom flange of the beam appeared. The P-4 specimen was failure because of the fracture of the two bolts in low row. The web of column (Fig. 18c) was deformed significantly (buckled at the height of the upper row of bolts).

a)
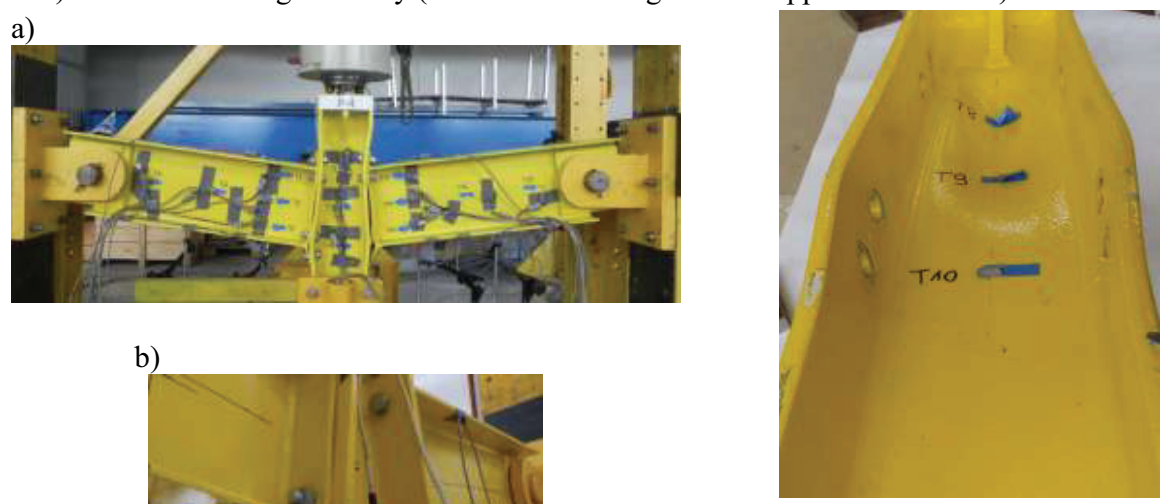

b)

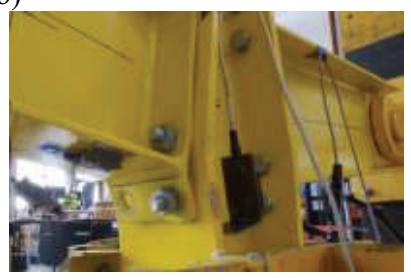

Fig.18. P-4 specimen: a) view after failure, b) failure mode of specimen, c) column view after test

The strains of the P-4 specimen in selected locations were shown in Fig. 19. In the beams (Fig.18a, 19b), a linear increase in strain occurred till a load of $350 \mathrm{kN}$. Only differences can be seen in the T4 strain gauge. Then, the further increase in the loading caused a decrease in deformation in the compression zone and its increase in the tensile zone. The strain values in the strain gauges set in the beam axis were similar.

a)

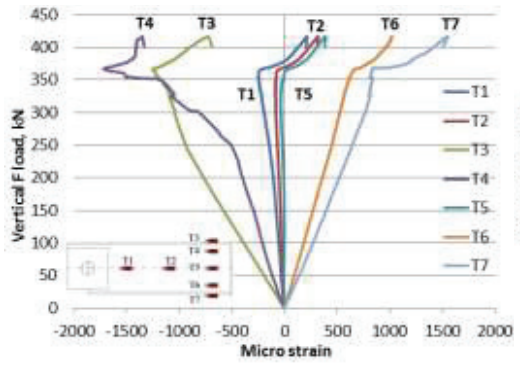

b)

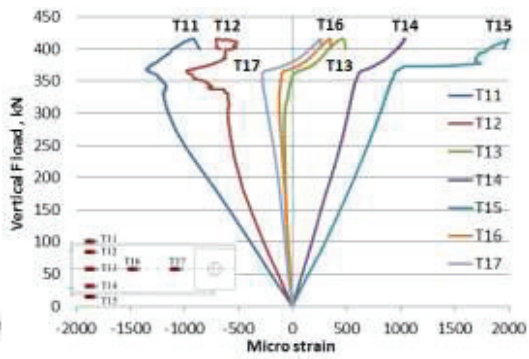

c) 


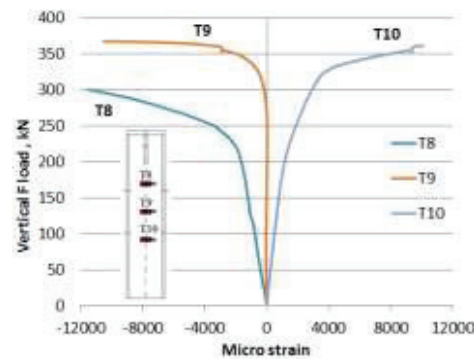

Fig.19. Strain distribution of P-4 specimen: a) left beam, b) right beam, c) column

The strains distribution in the column is shown in Fig. 19c. Up to $200 \mathrm{kN}$, one can notice a linear increase in the strains T8 and T10 followed by non-linear increase. The T9 strain gauge remained without deformation up to the loading of $300 \mathrm{kN}$, afterthat there was an increase in compression strains observed.

\subsection{P-5 SPECIMEN -15 MM THICK END PLATE}

From the beginning of the test there was a constant increase in the F loading of the specimen up to about $250 \mathrm{kN}$ (Fig. 20a). After exceeding the value of $250 \mathrm{kN}$, the specimen deflection increased. The specimen showed slowly increase in load-bearing capacity until the end of the test. The development of the horizontal axial $\mathrm{H}$ force in the beams varied during the test. From the beginning to $30 \mathrm{~mm}$ of deflection, horizontal $\mathrm{H}$ force caused compression. After exceeding $30 \mathrm{~mm}$ of deflection, the catenary action developed until the specimen was destroyed. The connection behavior (Fig. 20b) can be divided into two phases: elastic and plastic. In the elastic phase, there was a constant increase of moment from the beginning of the test to a bending moment equal to 130 $\mathrm{kNm}$. Then further increase of the load caused an increase in the rotation of the connection. After obtaining a rotation of 0.03 radians, the bending moment in connections started to decrease linearly.

a)

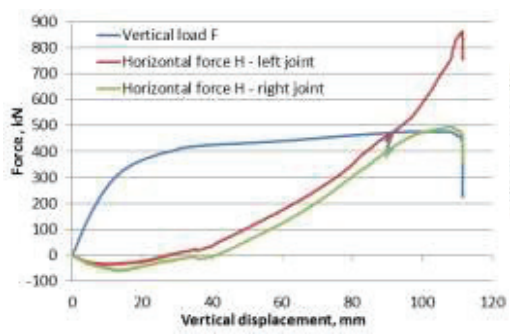

b)

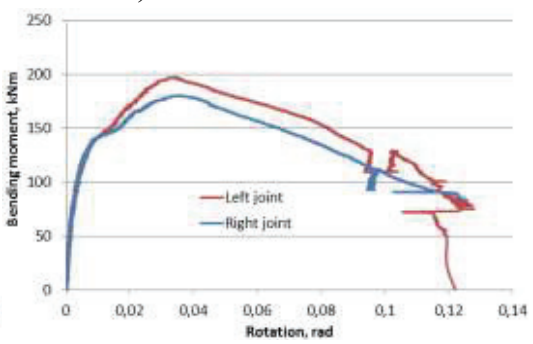

Fig.20. P-5 specimen: a) vertical load and horizontal force vs. vertical displacement, b) bending moment vs. joint rotation

Until a load of $250 \mathrm{kN}$ was achieved, no visible changes in the specimen were observed. After exceeding this value, the column flanges were compressed at the level of the upper beam flange. 
Then, at $420 \mathrm{kN}$, there was a gap between the surface plate and the column flanges at the height of the lower beam (Fig. 21a). Then there was a fracture in the weld (Fig. 21b) connecting the bottom flange of the beam with the end plate. Because of the fracture of the two bolts in low row the P-5 specimen was damaged. After the test, significant deformation of the column web (Fig. 21c) can be noted at the height of the top rows of bolts. This buckling was caused by high compressive forces from the top flange beam.

a)

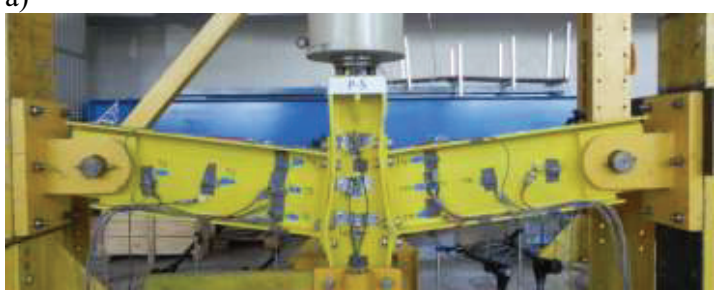

c)

b)
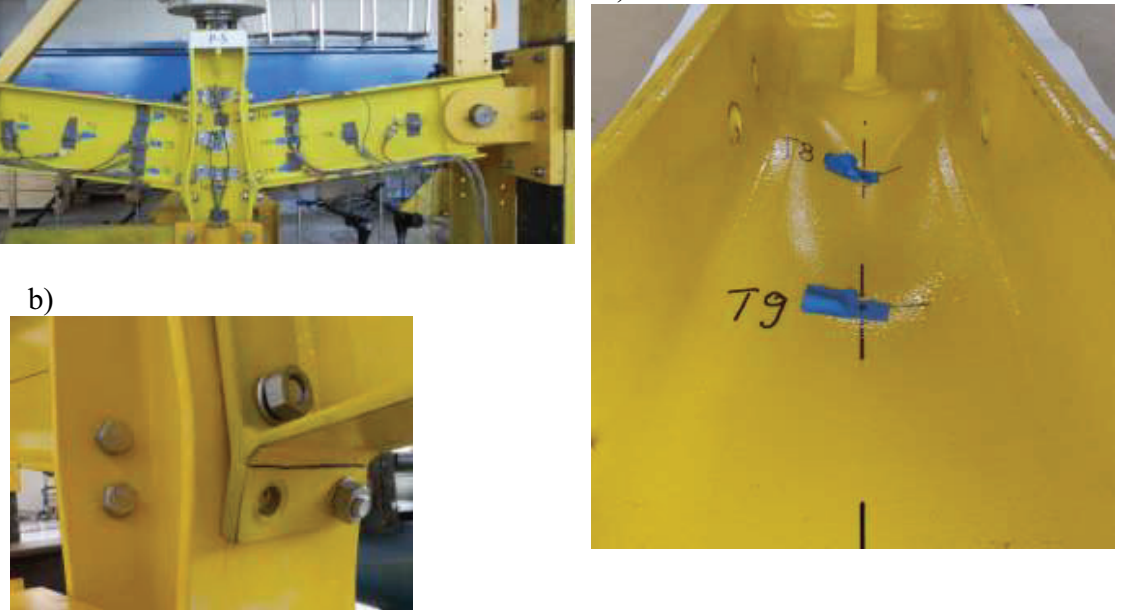

Fig.21. P-5 specimen: a) view after failure, b) failure mode of specimen, c) column view after test

The linear increase in beam strains in the initial phase of the test is presented in Figs. 22a and 22b. As in the previous results of the P-4 specimen, after linear increments, a significant change in the strains values occurred. The strain gauges in the beam axis up to $420 \mathrm{kN}$ showed negligible values. After exceeding $420 \mathrm{kN}$, the tensile strain increased.

a)

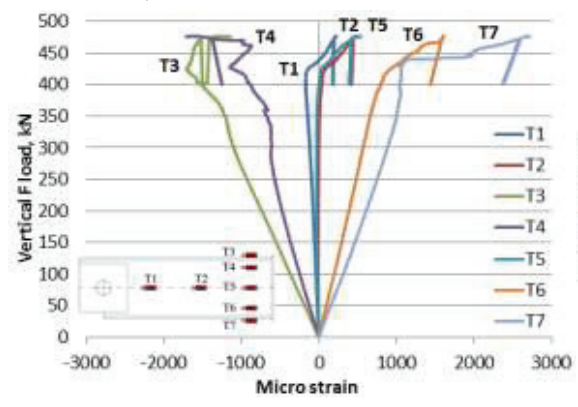

b)

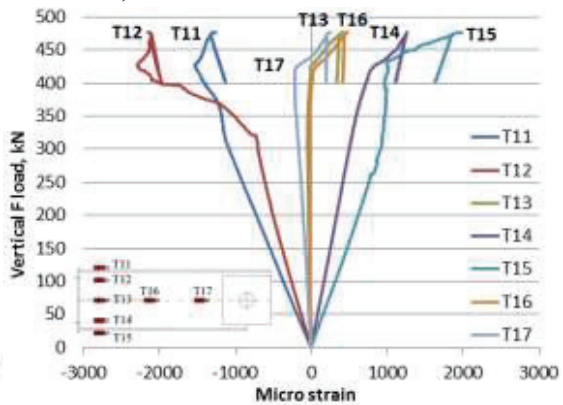

c) 


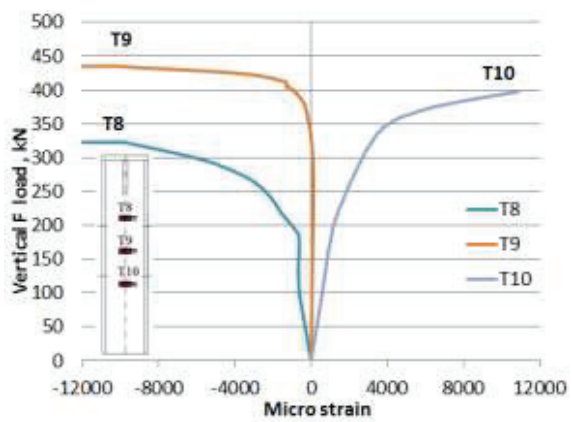

Fig.22. Strain distribution of P-5 specimen: a) left beam, b) right beam, c) column

The development of the column strains in the joint zone is presented in Figure 23c. Strain gauges T8 and T10 show the linear increment of deformations up to $150 \mathrm{kN}$ of the load and then the strain values increased rapidly. Furthermore, the test range in stain gauge was exceeded and they were damaged with a load of $325 \mathrm{kN}$ for T8 and $400 \mathrm{kN}$ for T10. Up to the force of $350 \mathrm{kN}$, the T9 strain gauge remained in the range of very small strains, where after reaching $350 \mathrm{kN}$ there was an increase in compressive strain.

\subsection{P-6 SPECIMEN -20 MM THICK END PLATE}

The constant increase of load $\mathrm{F}$ from the beginning of the test to about $250 \mathrm{kN}$ can be observed in Fig. 23a. Then there was an increase in the vertical displacement with a smaller increase of loading. The horizontal axial $\mathrm{H}$ force in the beams from the beginning of the test up to $13 \mathrm{~mm}$ of deflection was approximately zero. After reaching a deflection of $13 \mathrm{~mm}$, the compressive $\mathrm{H}$ force in the right beam was developed until the $53 \mathrm{~mm}$ deflection. After that a linear development of the tensile action took place in the right beam. On the other hand, the left beam has shown the development of a tensile action. The behavior of the P-6 specimen connections is shown at the Fig. 23b. It can be noticed that the connection exhibited linear behavior up to approximately $100 \mathrm{kNm}$. After exceeding this value, the rotation increase non-linearly. After exceeding the rotation of connections equal to 0.05 radians there was a continuous decrease of the bending moment in the joints.

a)

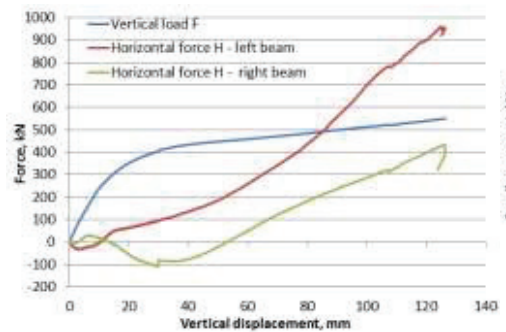

b)

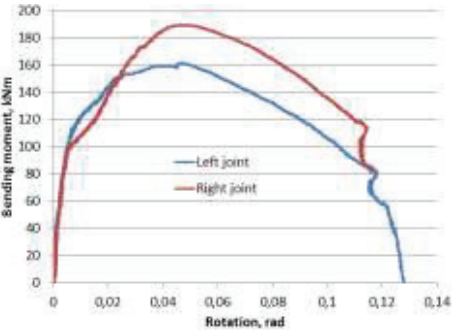

Fig.23. P-6 specimen: a) vertical load and horizontal force vs. vertical displacement, b) bending moment vs. joint rotation 
In the initial phase of loading up to $220 \mathrm{kN}$ no changes were observed in the specimen. Then, small deformation of the column flanges in the connection zone began to appear at the height of the lower beam flange. At the force of $425 \mathrm{kN}$, deformations of the web and the column flanges in the level of the upper rows of bolts began to emerge. Before the end of the test (Fig. 24a), it was possible to notice the torsion of a part of the column above the level of the upper beam flange. This was caused by large deformations of the column's web. Interestingly, the specimen was not damaged because the maximum load generated by the actuator of $550 \mathrm{kN}$ was reached and the actuator started to fall into dynamic resonance. The buckling of the column's web from the main plane of the specimen can be observed in Fig. 24b.

a)

b)

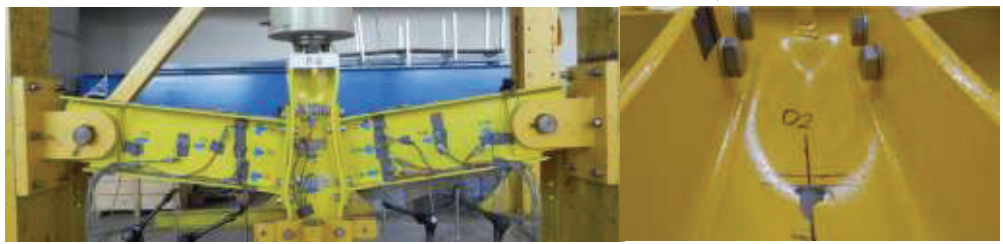

Fig.24. P-5 specimen: a) view before ending test, b) column view after test

The strains pattern of the P-6 specimen (Fig. 25a, b) can be divided into two zones. The first zone is the linear increment of deformations from the beginning of the tests to the value of $440 \mathrm{kN}$. The second zone is characterized by a distinct increase in strains in the lower flange beam for T6, T7 and T14 and T15 strain gauges.

a)

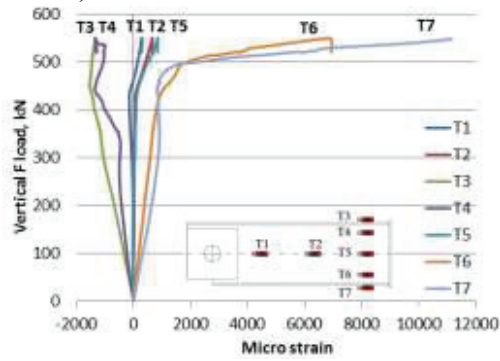

b)

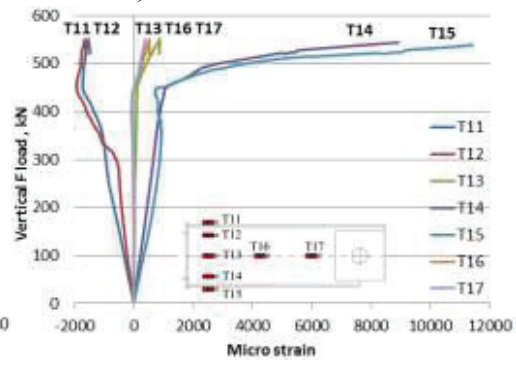

c)

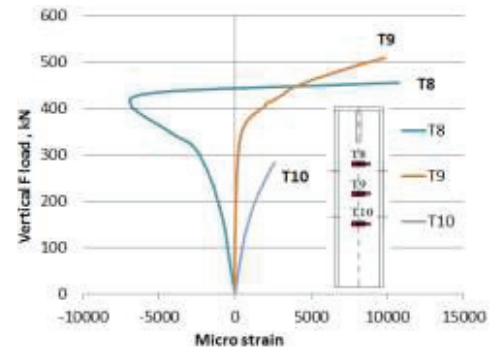

Fig.25. Strain distribution of P-6 specimen: a) left beam, b) right beam, c) column 
Interesting behavior can be noticed by observing column strains (Fig. 25c). The T8 strain gauge located at the height of the upper beam flange changed the deformation values significantly. To achieve a load of $400 \mathrm{kN}$ there were compression strains in it. After exceeding $400 \mathrm{kN}$, there was a significant decrease in compression strains and a change in the mark to tensile strain. The deformations in the T9 and T10 strain gauges also showed positive values in the final phase of the test. Thus, during the final test period, only tensile strains occurred in the joint zone.

\subsection{COMPARISON OF TEST RESULTS}

A summary of the test results of isolated joints is presented in Table 4.The table shows the connection parameters: yield and plastic moment resistance $\left(\mathrm{M}_{\mathrm{y}}\right.$ and $\mathrm{M}_{\mathrm{u}}$ respectively) of the joint and the maximum rotation angle. The maximum horizontal $\mathrm{H}$ force in the beam axis was also given, which represented the axial force created in the catenary action. The horizontal $\mathrm{H}$ force in the beam axis was determined on the basis of values of the strain gauges fixed in the beam axis. All tested joints meet the requirements of standard [12] for a minimum tensile force greater than or equal to $75 \mathrm{kN}$ what can be seen in Tab. 4.

Table4. Comparison of test results

\begin{tabular}{|c|c|c|c|c|c|c|c|c|}
\hline Specimen & End plate & $\begin{array}{c}\text { Plate } \\
\text { thickness }\end{array}$ & $\begin{array}{c}\text { Bolts } \\
\text { rows }\end{array}$ & $\begin{array}{c}\mathrm{M}_{\mathrm{y}} \\
{[\mathrm{kNm}]}\end{array}$ & $\begin{array}{c}\mathrm{M}_{\mathrm{u}} \\
{[\mathrm{kNm}]}\end{array}$ & $\begin{array}{c}\Phi_{\mathrm{u}} \\
{[\mathrm{rad}]}\end{array}$ & $\begin{array}{c}\mathrm{H}_{\mathrm{u}} \\
{[\mathrm{kN}]}\end{array}$ & $\begin{array}{c}\text { Development } \\
\text { of catenary } \\
\text { action }\end{array}$ \\
\hline P-1 & Flush & $10 \mathrm{~mm}$ & 2 & 72,38 & 97,61 & 0,108 & 590,76 & Yes \\
\hline P-2 & Flush & $15 \mathrm{~mm}$ & 2 & 71,25 & 91,19 & 0,084 & 754,20 & Yes \\
\hline P-3 & Flush & $20 \mathrm{~mm}$ & 2 & 77,13 & 91,84 & 0,109 & 905,17 & Yes \\
\hline P-4 & Extended & $10 \mathrm{~mm}$ & 4 & 137,61 & 150,67 & 0,126 & 576,53 & Yes \\
\hline P-5 & Extended & $15 \mathrm{~mm}$ & 4 & 138,46 & 197,22 & 0,108 & 864,70 & Yes \\
\hline P-6 & Extended & $20 \mathrm{~mm}$ & 4 & 98,72 & 189,94 & 0,135 & 960,74 & Yes \\
\hline
\end{tabular}

Designates: $\mathrm{M}_{\mathrm{y}}$ - yield moment capacity $[\mathrm{kNm}], \mathrm{M}_{\mathrm{u}}-$ ultimate moment capacity $[\mathrm{kNm}], \Phi_{\mathrm{u}}-$ maximum rotational capacity[rad], $\mathrm{H}_{\mathrm{u}}$ - maximum axial force in beam $[\mathrm{kN}]$

The connection tested as P-5 specimen has the highest bending capacity as shown in Fig. 26a. A clear division into two groups can be noticed: joints with flush and extended end-plate. Specimens with four rows of bolts gained greater load capacity than with two rows. Comparing the specimen P-1 and P-4, the bending capacity of the P-4 specimen is almost twice as high. The larger number of bolts and the thicker the plate, the higher the bending moment resistance was reached.

a)

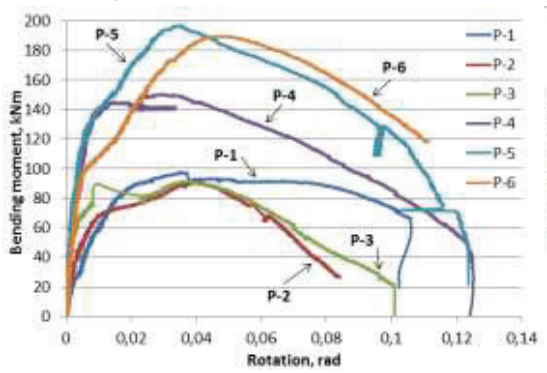

b)

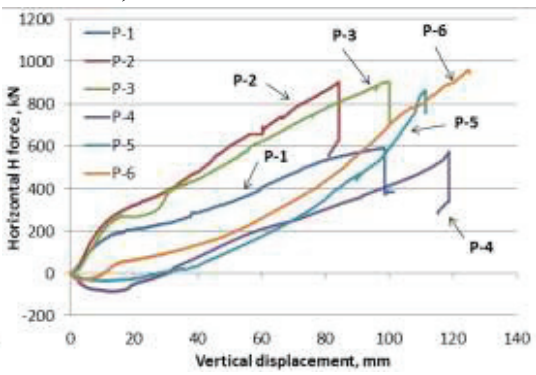

Fig. 26. Comparison:a)bending moment vs. rotation, b) horizontal force vs. vertical displacement 


\section{TEST OF END PLATE CONNECTION IN THE FRAME SUB-SYSTEM}

The tests of the steel frame subsystem $[15,19,24]$ were made on the specimen shown in Figure 27.

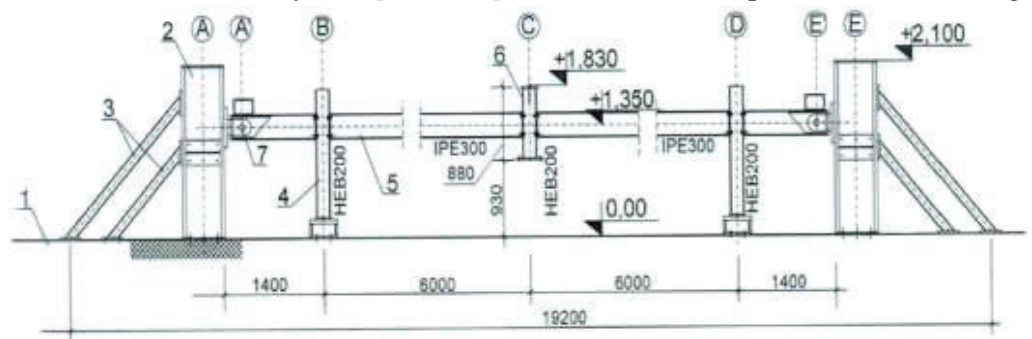

Fig. 27. Test setup: 1 - laboratory floor, 2- resistance stand element, 3- stand stability elements, 4- frame column, 5- frame beam, 6-middle frame column, 7- pin stand-to-side stand joint by [24]

Flush end-plate joints (fig. 28a) and extended end-plate (fig. 28b) with end plate $10 \mathrm{~mm}$ were used. Two or four rows of M20 bolts 10.9 were used.

a)

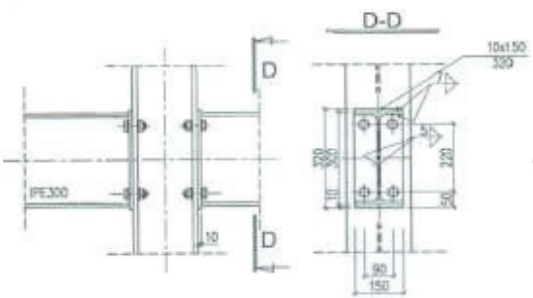

b)

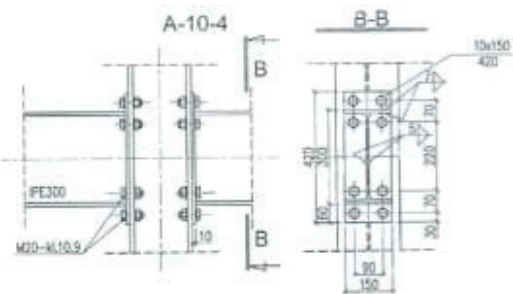

Fig. 28. Connection details: a) flush end-plate, b) extended end-plateby[24]

The results of testing the specimen with flush end-plates were shown in Fig. 29.The bending moment growth was constant to the loading creating a bending moment in the joint equal to 70 $\mathrm{kNm}$. After exceeding $70 \mathrm{kNm}$, there was a non-linear increase, while after $0,050 \mathrm{rad}$ of rotation there was a decrease in bending moment until destruction. The development of axial force in beams was shown in Figure 29b. Along with the increase of the bending moment in the joint, the axial force growth was almost linear.

a)

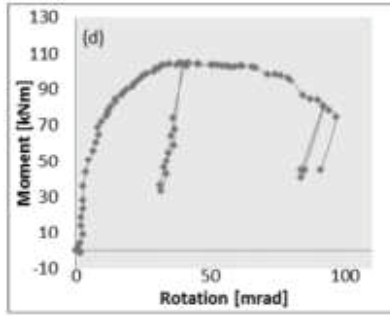

b)

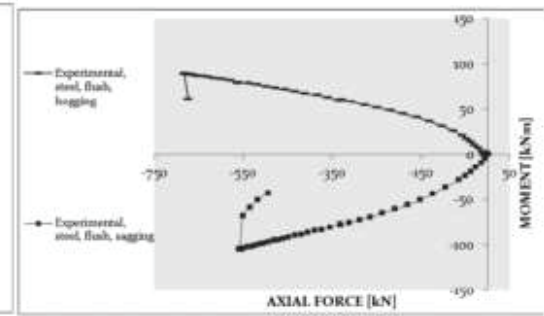

Fig. 29. Specimen with flush end connection: a) local characteristics moment-rotation of inner column joint under sagging bending, b)moment-force relationship of the flexular-membrane state at the inner and outer flush end plate joints (sign minus of the axial force refers to tension) by [24] 
The results of the test of the sub-system with extended end-plate joints are shown in Fig. 30.The increase in the bending moment was constant till the value of the moment of $120 \mathrm{kNm}$ in the joint (Fig. 30a). After exceeding $120 \mathrm{kNm}$, the connection behavior was non-linear. From the beginning of the test (Fig. 25b) a linear increase in value of axial force in the beams was shown. The failure mode of both subsystems was the tearing of the end plate in the lower zone of the flange beam.

a)

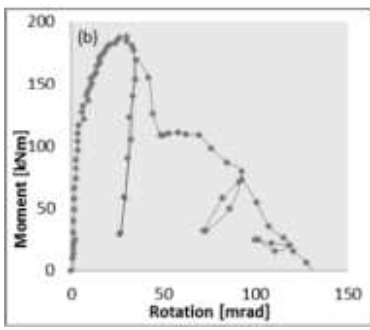

b)

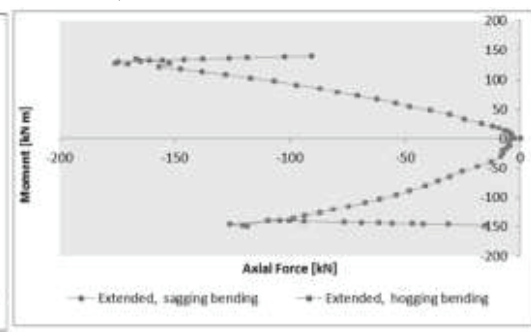

Fig. 30. Specimen with extended end connection: a) local characteristics moment-rotation of inner column joint under sagging bending, b)moment-force relationship of the flexular-membrane state at the inner and outer flush end plate joints (sign minus of the axial force refers to tension) by [24]

The comparison of the own test results of isolated joints with results of tests conducted on the subframe [24] was presented in Fig. 31 and 32. The results of the P-1 specimen (flush plate $10 \mathrm{~mm}$ thick) were compared with the results of the subsystem with flush end-plate joints (end plate thickness $10 \mathrm{~mm}$ ). The first graph (Fig. 31a) shows the moment-rotation characteristics of the inner connection. As can be seen, the behavior of both connections was the same at the initial stage. After exceeding the bending moment of $60 \mathrm{kNm}$ there were slight changes in the behavior of the connections. Both joints obtained a similar angle of rotation of the joint in case of failure. The development of axial force in both tests is shown in Fig. 31b. From the beginning of own experiment of the P-1 specimen, there was a tensile axial force with non-linear behavior. During the whole range of loading in tests presented in studies [24], there was a linear increase of tension force in the joints.

a)

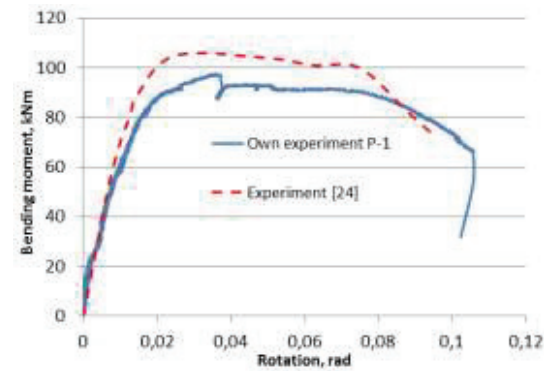

b)

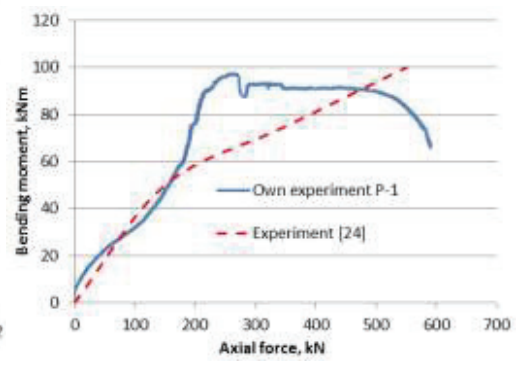

Fig. 31. Comparison results of flush end-plate connection:a) moment - rotation, b) moment — axial force in beam 
The second comparison, of the P-4 specimen (extended plate $10 \mathrm{~mm}$ thick) with a sub-system with extended end-plate joints with a plate of a thickness of $10 \mathrm{~mm} \mathrm{[24]} \mathrm{was} \mathrm{presented} \mathrm{in} \mathrm{Fig.} \mathrm{32.} \mathrm{In} \mathrm{the}$ range from 0 to $140 \mathrm{kNm}$ of bending moment in the joint, the behavior of both connections was the same. From $150 \mathrm{kNm}$, the difference in the behavior of connections began to clearly differ. The P-4 specimen (own research) shows further development of the joint rotation with a decrease of the moment in the joint. The connection tested in [24] reached the peak of load capacity at the rotation of $0.03 \mathrm{rad}$, and then showed a significant decrease of bending moment. The connection of the P-4 specimen was subjected to sudden failure (fracture of bolts) while the connection from the tests [24] of gradual degradation by end-plate tearing. At the initial stage of the test of the P-4 specimen, there was a compressive axial $\mathrm{H}$ force up to a value of $140 \mathrm{kNm}$, followed by an intensive development of the catenary action (Fig. 32b). In test [24] the development of the tensile force took place throughout the loading. Differences in the behavior of joints in own test and test [24] may resulted from the different stiffness of the horizontal test setup. In own test (Figure 5), horizontal stiffness, in the specimen plane, for a column with one brace was $225 \mathrm{kN} / \mathrm{mm}$. In test [24], however, in the external support of the end columns (Fig. 27), two braces were applied per side, which significantly increased the stiffness of the supports.

a)

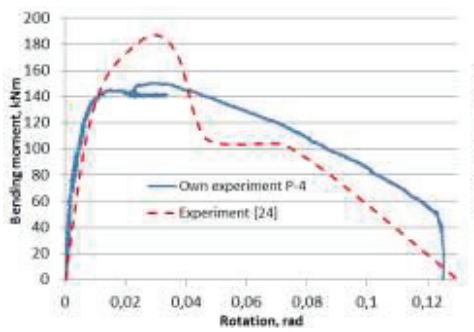

b)

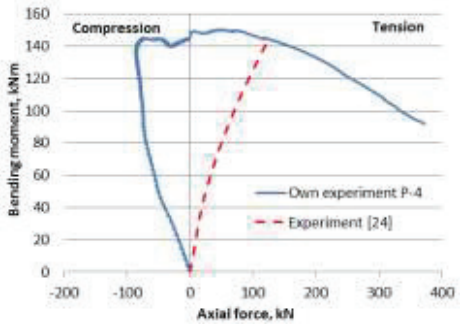

Fig. 32. Comparison results of extended end plate connection: a) moment - rotation, b) moment —axial force

\section{DISCUSSION AND CONCLUSION}

Based on the conducted tests, it can be concluded that:

- the working phase of end plate joints can be divided into three stages: elastic, plastic and plastic with the development of horizontal forces in beams,

- in the initial phase of the loading, the small horizontal compression force is generated due to the arc action in the beams with extended plate (Fig. 33a). From the beginning of the loading, the connections with flush plate show the ability to create a catenary action (fig. 33b).

- an important aspect of the development of horizontal force in the beam axis is the possibility of deformation of the connection parts, 
a)

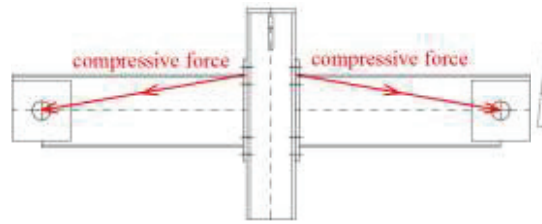

b)

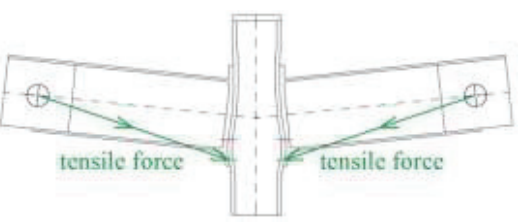

Fig. 33. Horizontal force development phases in the beam axis a) arch action, b) catenary action

- amongst the end-plate bolted connections with flush end-plate and extended end-plate, the highest bending resistance was obtained in connections with plate $15 \mathrm{~mm}$ (specimen P-5),

- end-plate joints with extended plate (EP) show a greater capacity to develop catenary action than connections with flush plate - stronger tensile zone (4 tension bolts) was the main reason,

- the use of thicker end plates increases the bending capacity and the development of catenary action for unstiffened columns,

- connections with a strong tensile zone allow the creation of large forces in the compression zone of the joint (column web), which leads to a significant buckling of the unstiffened column web, - the lack of stiffeners of the column web allows large deformations of the flanges and the web of the column, contributing to the increase in the rotation of connections significantly,

- in initial stage of loading, vertical F load of column is transferred to the beam by bending joints,

- in the further phase of the loading, the vertical F force in the column is transferred mainly through the horizontal axial $\mathrm{H}$ forces in the beams,

- good convergence of results of own test with test at work [24] was observed.

The obtained results of connection tests will be also used to validate numerical models of connections. In future studies, numerical analyzes as well as further experimental tests of the influence of horizontal stiffness of supports on available bending resistance, rotation capacity and the possibility of developing a catenary action will be made.

\section{REFERENCES}

[1] Barata P., Santiago A.,Riguerio C., Rodrigues J. P. : Experimental behaviour of beam-to-column steel joints subjected to impact loading, Eight International Conference of Advanced Steel Structure, Lisbon, Portugal, July 2224, 2015.

[2] British Standards Institution, BS 5950: Structural use of steelwork in buildings, Part 1: Code of practice for design rolled and welded section, London, 2000.

[3] Cortes G. Liu J.:Behavior of conventional and enhanced gravity connections subjected to column loss, Journal of Constructional Steel Research 133 (2017), p. 475-484. http://dx.doi.org/10.1016/j.jcsr.2017.02.028

[4] D’AntimoM.,Latour M., Rizzano G., Jaspart J-P., Demonceau J-F.: Preliminary study on beam-to-column joints under impact loading, The Open Construction and Building Technology Journal, 2018, 12,p.-112-123, DOI: $10.2174 / 1874836801812010112$.

[5] Demonceau J-F, Jaspart J-P. :Experimental test simulating a column loss in a composite frame, Advances Steel Construction Vol. 6, No 3. P.891-913 (2010)

[6] Department of Defence (DoD), Unified facilities criteria (UFC): Design of structures to resist progressive collapse, Washington, 2005.

[7] Dinu F., Marginean I., DubinaD.:Experimental testing and numerical modeling of steel moment frame connections under column loss, Engineering Structure 151 (2017) 861-879. http://dx.doi.org/10.1016/j.engstruct2017.08.068. 
[8] Dinu F., Marginean I., Dubina D., Pertan I.: Experimental testing and numerical modeling of 3D frame under column loss, Engineering Structure 113 (2016) 59-70. http://dx.doi.org/10.1016/j.engstruct2016.01.022.

[9] Dinu F., Marginean I., Dubina D., Pertan I.: Experimental study of seismic resistant steel frames in case of column, Eight International Conference on Advances in Steel Structures, Lisbon, Portugal, July 22-24, 2015.

[10] EN 10002-1 Metallic materials - Tensile testing-Part 1: Method of test at ambient temperature, CEN Brussels, 2001.

[11] EN 1990 Eurocode - Basis of structural design, European Committee for Standardization CEN Brussels, 2002.

[12] EN 1991-1-7: Eurocode 1, Actions on structures, part 1-7: General actions - Accidental actions, European Committee for Standardization CEN Brussels, 2006.

[13] EN1993-1-1: Eurocode 3, Design of steel structures, Part 1-1: General rules and rules for buildings, European Committee for Standardization CEN Brussels, 2005.

[14] EN 1993-1-8 Eurocode 3 Design of steel structures, Part 1-8: Design of joints, European Committee for Standardization CEN Brussels, 2005.

[15] Giżejowski M. A., Barcewicz W.: Thin end-plate beam-to-column composite joints investigations of the behaviour of steel-composite joints, Eurosteel2008, 3-5 Graz, Austria, 2008.

[16] GiżejowskiM.A., Kwaśniewski L., Saleh B., Balcerzak M.: Numerical Study of Joints behavior for Robustness Assessment. Journal of Applied mechanics and materials, vol. 166-169, 2012, p. 3114-3117.

[17] Giżejowski M. A., Szwed A.,Saleh A.A.K., Barcewicz W.: Joint moment-rotation characteristic in light of experimental simulations of frame column loss, Journal of civil engineering, environment and architecture, t.XXX z.60 (2/13), april-june 2013, p. 51-76

[18] General Services Administration (GSA), Progressive collapse analysis and design guidelines for a new federal office buildings and major modernization project, 2003.

[19] Kozłowski A., Giżejowski M., Ślęczka L., Pisarek Z., Saleh B.: Experimental investigations of the joint behaviorRobustness assessment of steel and steel-concrete composite frames, Proceeding of the $6^{\text {th }}$ European Conference on Steel and Composite Structures, Budapest 2011, vol. A, pp. 339-344.

[20] Kuhlmann U, Rolle L., Jaspart J.-P., Demonceau J.-F., Vassart O., Weynand K., Ziller C., Busse E., Lendering M., Zandonini R., Baldassino N.: Robust structure by joint ductility, Final report of the RFCS project $\mathrm{n}^{\circ}$ RFS-CR04046, 2008,European Commission, Luxembourg, ISBN 978-92-79-10360-5.

[21] Li H., Cai X., Yhang Y., Yhang B., Wang W.,: Progressive collapse of steel moment-resisting frame subjected to loss interior column:Experimental tests, Enginerring Structures 150 (2017), p. 203-220, http://dx.doi.org/10.1016/j.engstruct.2017.07.051

[22] Meng B. Zhong W. Hao J.: Anti-collapse performance of the steel beam-to-column assemblies with different span $\begin{array}{lllllll}\text { ratios, Journal of Constructional Steel Research } 140 & \text { (2018), } & \text { p. } & 125-138 .\end{array}$ http://dx.doi.org/10.1016/j.jcsr.2017.10.014

[23] Prinz G. S., Nussbaumer A. , Borges L., Khadka S.: Experimental testing and simulation of bolted beam-column connections having thick endplates and multiple bolts per row, Engineering Structures 59 (2014), p.434-447, http://dx.doi.org/10.1016/i.engstruct.2013.10.042

[24] Saleh B.: Modeling of beam-to-column joints of steel concrete composite frames subjected to standard and extreme load combinations, PH.D. thesis, Warsaw 2013

[25] Song B. I. Giriunas K. A. Sezen H. : Progressive collapse testing and analysis of a steel frame building, Journal of Constructional Steel Research 94 (2014), p. 76-83. http://dx.doi.org/10.1016/j.jcsr.2013.11.002

[26] Song B. I. Sezen H.: Experimental and analytical progressive collapse assessment of a steel frame building, Enginerring Structures 58 (2013), p. 664-672, http://dx.doi.org/10.1016/j.engstruct.2013.05.050

[27] Woliński S.: Defining of the structural robustness, Bulletin of the Polish Academy of Sciences, Technical Sciences, Vol. 61, No 1, 2013.

[28] Yang B., Tan K. H.: Experimental tests of different types of bolted steel beam-column joints under a central$\begin{array}{llllll}\text { column-removal } \quad \text { scenario, } & \text { Engineering } & \text { Structures } & 54 & \text { (2013), } & \text { p.112-130, }\end{array}$ http://dx.doi.org/10.1016/i.engstruct.2013.03.037 


\title{
BADANIA DOŚWIADCZALNE DOCZOLOWYCH OBUSTRONNYCH NIEUŻEBROWANYCH WĘZLÓW Z BLACHĄ WPUSZCZONĄ I WYSTAJĄCĄ
}

\author{
KOZLOWSKI ALEKSANDER ${ }^{1}$, KUKLA DAMIAN ${ }^{2}$
}

\begin{abstract}
W artykule przedstawiono badania doświadczalne śrubowych doczołowych nieużebrowanych węzłów obustronnych. Głównym celem badań było sprawdzenie możliwości utworzenia mechanizmu wtórnego, tzw. akcji cięgnowej w scenariuszu utraty słupa. Badaniu poddano dwa typy wezłów doczołowych: z blachą wpuszczoną (FP) i z blachą wystającą (EP) o różnej grubości oraz różnej liczbie rzędów śrub. Badania wykonano na wyizolowanym układzie krzyżowym belka-słup-belka do momentu zniszczenia połączenia. Wynikiem badań było określenie nośności połączeń przy zginaniu, ustalenie zdolności do obrotu tego typu połączeń oraz ustalenie wartości sił rozciągających w belkach. Połączenia z blachą wystającą wykazały większą nośność na zginanie oraz zdolność do obrotu niż węzły z blachą wpuszczoną. Miejscami znacznych odkształceń węzła były pasy i środnik słupa oraz blacha czołowa. Modelem zniszczenia węzłów było zerwanie śrub. Uzyskane w badaniach wartości siły osiowej w belkach przekroczyły wartości normowe, co potwierdza, że połączenia $\mathrm{z}$ nieużebrowanym środnikiem słupa, z blachą wpuszczoną lub blachą wystającą posiadają zdolność rozwoju akcji cięgnowej.
\end{abstract}

Słowa kluczowe: stalowe węzły doczołowe, badania doświadczalne, połączenie belka-słup, robustness, węzły podatne, akcja cięgnowa, utrata słupa, 